\title{
SNOWTRANS
}

\section{Regionalisation of snow- and ice melt processes in the Hohe Tauern mountains in Austria"}

\section{Summary Report}

Holzmann, H. ${ }^{1)}$, W. Schöner ${ }^{2)}$, G. Koboltschnig ${ }^{1)}$, Ch. Kroisleitner ${ }^{2)}$, B. Hynek ${ }^{2)}$, R. Mott ${ }^{2)}$, G. Michlmayer ${ }^{1)}$, W. Schneider ${ }^{3)}$, G. Kaiser ${ }^{3)}$, M. Vollmann ${ }^{3)}$, L. Rauch ${ }^{1)}$

1) Inst. for Water Management, Hydrology and Hydraulic Engineering. Univ. for Natural Resources and Applied Life Science, Vienna.

2) Central Institute of Meteorology and Geodynamics, Department of Climatology, Vienna

3) Inst. of Surveying, Remote Sensing and Land Information (IVFL). Univ. for Natural Resources and Applied Life Science, Vienna.
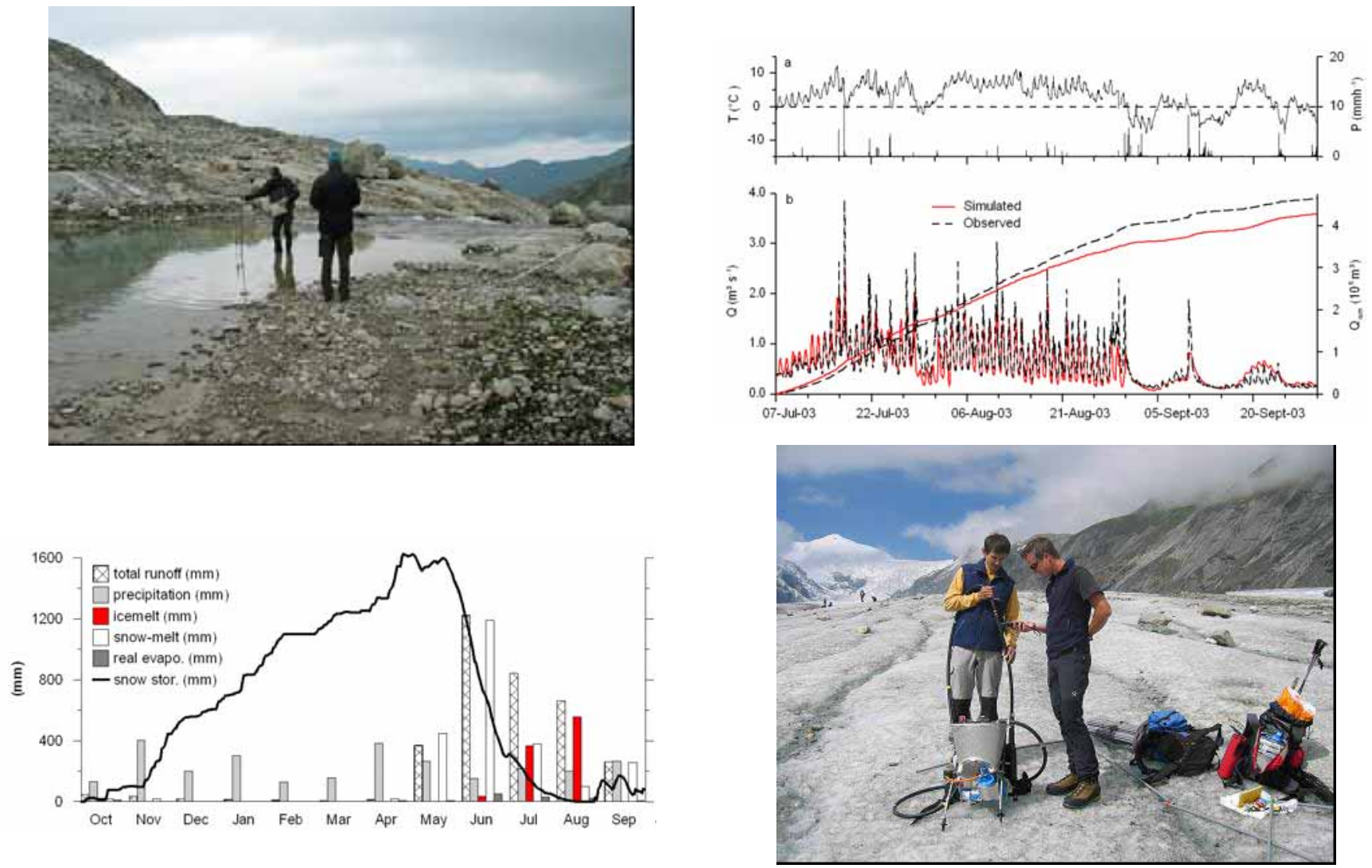

ISBN: 978-3-7001-3987-4

DOI : 10.1553/ snowtrans07

Vienna, Feb. 2008

Funded by the Austrian Academy of Sciences
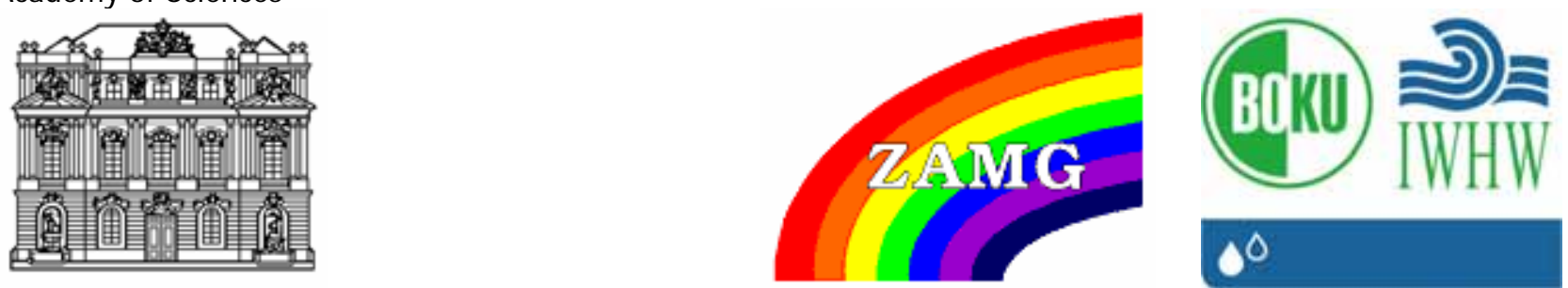


\section{Summary}

The project SNOWTRANS (Transformation of observed and computed ice- and snowmelt data to ungauged basins) was performed within the Austrian Academy of Sciences (ÖAW) call for contributions to the UNESCO hydrological decade initiative of PUB (prediction in ungauged basins). Contributing to this general objective of PUB, SNOWTRANS firstly aimed to deliver a better understanding of high Alpine snow- and ice melt processes by means of detailed field measurements and modelling results from a well observed highly glacierized test basin (Rauriser Sonnblick, Goldbergkees, Austrian Alps). As a second major task of the SNOWTRANS project various sufficiently calibrated snow- and ice melt models are tested for their potential to be applied for sparsly gauged or ungauged basins.

The Sonnblick region stands out because of its detailed and long-term monitoring of meteorological, hydrological and glaciological data which enabled not only the application of index-based melt model approaches (e.g. PREVAH, BOKU-model) but also to fully model evolution of the winter snow cover by means of the physically based ALPINE3D model. ALPINE3D includes a couple of sub-models capturing snow drift (initialized from turbulent kinetic energy of the mesoscale model ARPS) as well as energy and mass balance of the snow cover. Within the frame of SNOWTRANS for the first time a full winter-season (October to May) was modelled using the ALPINE3D model and was validated against field data with great modelling success. Our results show the high influence of wind drift on snow redistribution which causes a systematic bias for the majority of index based models.

The simulations of the runoff in the test basins rely both on the meteorological driving forces like rainfall, temperature and radiation and on the snow and ice melt estimates. The lack of snow drift concepts lead to local deviations in snow accumulation. But also the estimation of the spatio-temporal rainfall distribution based on the high altitude observations required some corrections. The index based melt methods comprised both pure temperature index and mixed temperature - radiation index concepts. Additionally a radiation balance concept integrated in the ALPINE3D model was applied. The spatial resolutions of the applied models were based on fully distributed grids (ALPINE3D), semi distributed hydrological response units (PREVAH) and elevation bands (BOKU model). The accumulated runoff at the basin outlet was reliably modelled by all concepts. The diurnal variation in discharge during the summer periods was satisfactory simulated by the mixed index approaches considering radiation, where the simple temperature index approach could not reproduce the daily variability. Snow layers exhibited to retain rainfall or melt water considerably, where ice melt rapidly contributed to runoff. 


\section{Content}

1. Objectives of the project..................................................................... 3

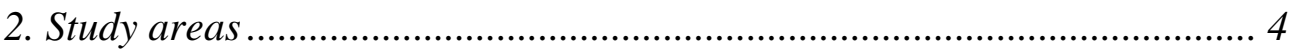

3. Monitoring and field observations .......................................................... 5

4. Modelling of snow and ice melt processes ................................................. 8

5. Modelling of snow drift ........................................................................ 22

6. Remote sensing .................................................................................... 23

7. Summary and conclusions .................................................................... 27

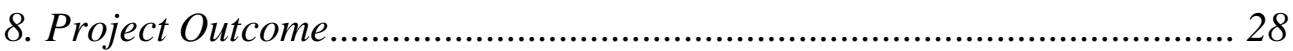

9. Acknowledgements .................................................................................. 32

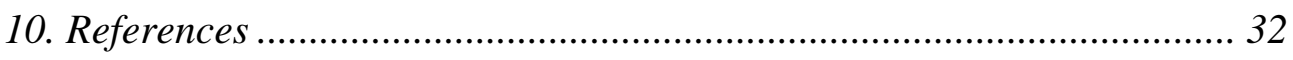

\section{Objectives of the project}

Snow accumulation and snowmelt are important processes for water storage and runoff formation in alpine environments. However due to the exposed and remote location hydrometeorological data are sparsely available for high elevated sites. Therefore state conditions of the hydrological system are generally obtained from simulation results of snowmelt models. These model types range from simple index models to physically based energy balance models. However, the required input data for such models exhibit high spatial variability due to orographic effects. Consequently, the major tasks of SNOWTRANS were to provide adequate data and to develop and adapt appropriate snow-cover models. Additionally, special emphasize was given to the regionalisation of the driving input data because of its high spatial variability.

For the test basin of the Goldbergkees (Sonnblick region, Austrian Alps, area $2.7 \mathrm{~km}^{2}$ ) an excellent data base of hydro-meteorological variables is available and therefore this area was selected to apply and to improve existing distributed snow accumulation and snowmelt models. Additionally, a complex energy balance model was applied to cover snowmetamorphism processes. Finally, the extrapolation to nearby ungauged basins was achieved by both simplifying the model structure as well as decreasing the spatial resolution of computational grid. In the frame of SNOWTRANS models based on distributed, combined temperature and radiation index approaches were used. The runoff formation process was considered both by means of a distributed and a lumped conceptual runoff model.

The developed snowmelt models were applied and validated for nearby sparsly gauged or ungauged basins with basin areas, ranging from $19 \mathrm{~km}^{2}$ to $580 \mathrm{~km}^{2}$. Independent variables like elevation, soil cover and aspect were used to define the spatial discretization units considering the particular characteristics of the test basins. Several model parameters describing the melt and runoff formation processes were transferred from the calibration 
basin. The validation of model results was done by means of discharge measurements and estimates of both the total melt release and spatial patterns of snow cover depletion from surveys and analysis of satellite images.

\section{Study areas}

The investigations on snow and ice melt processes were applied for different spatial scales. The small scale catchment was represented by the Goldbergkees area at Rauriser (Hoher) Sonnblick mountain (approx. $2.7 \mathrm{~km}^{2}$ ). This basin served as the reference basin for the various applied modelling approaches and field measurement techniques as this region benefits from the available data base of the meteorological observatory and hydroglaciological network. The medium basin scale was applied for the Obersulzbach runoff gauge Kees $\left(19 \mathrm{~km}^{2}\right)$ and the gauge Sulzau $\left(89 \mathrm{~km}^{2}\right)$, the large basin scale $\left(590 \mathrm{~km}^{2}\right)$ was represented by runoff gauge Salzach/Mittersill. The latter was also used to test and validate semi-distributed hydrological models by means of remote sensing techniques.

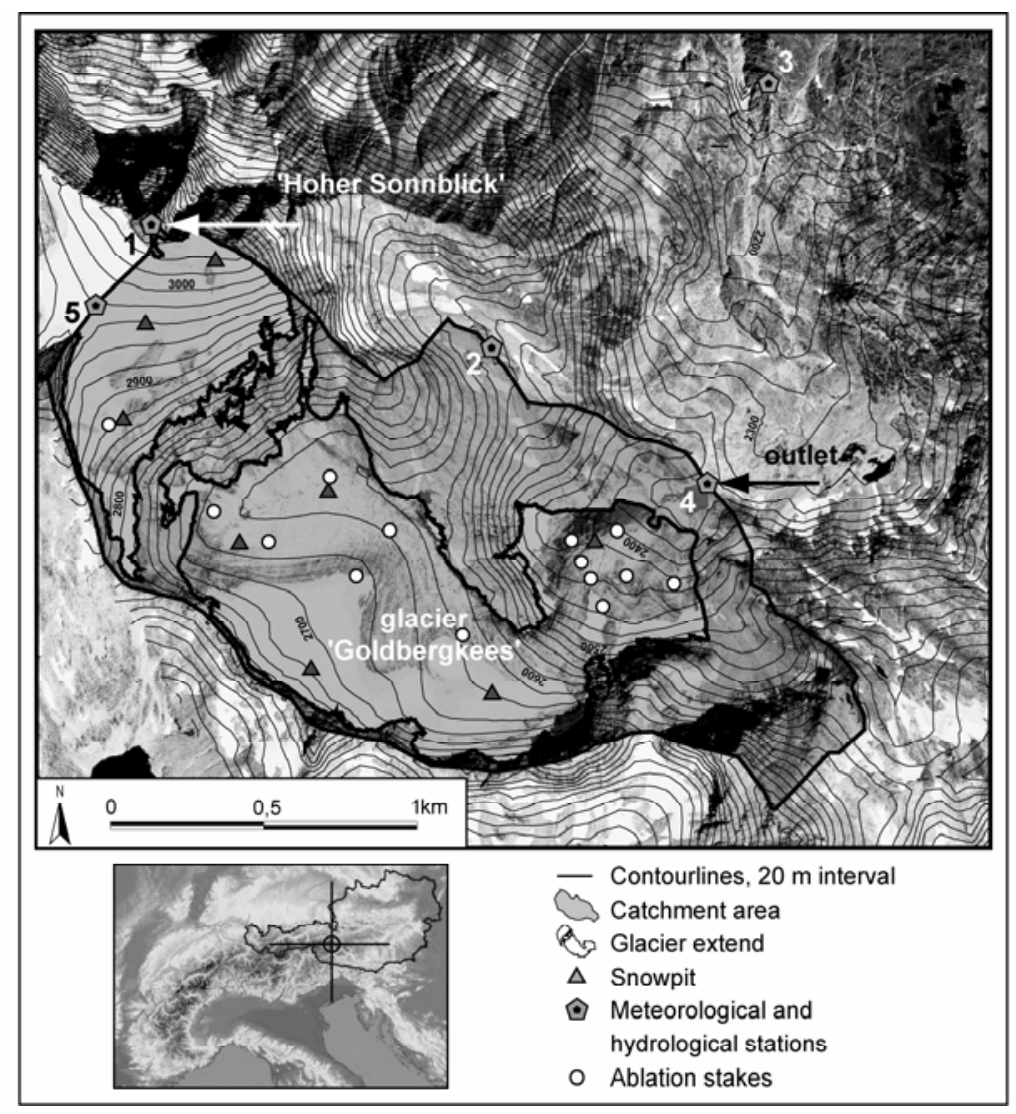

Figure 1: Basin Goldbergkees. Observatory at the top (3106 m a. sl.) and runoff gauge at the basin outlet (2350 m. a. sl.) from Koboltschnig (2007a).

Mount “Hoher Sonnblick” (4703’16” N, 12 ${ }^{\circ} 57^{\prime} 25^{\prime}$ ” E), as a major peak of Hohe Tauern region in the Austrian Alps is well known because of the meteorological observatory on its top at $3106 \mathrm{~m}$ a.m.s.l.. The observatory offers a wide spectrum of meteorological and climatological measurements back to the year 1886. Additionally, the Sonnblick region stands out because of a detailed glacier monitoring programme since about 25 years including Goldbergkees, close to the observatory (see Fig. 1). The watershed of the Goldbergkees basin 
is more than $50 \%$ glacierized (about $1,5 \mathrm{~km}^{2}$ - computed for 1998) and its elevation is ranging between 2350 and $3106 \mathrm{~m}$ a.m.s.l.

The basin of Obersulzbach is divided into two sub-catchments with respect to the gauging stations Kees $\left(19 \mathrm{~km}^{2}\right)$ and Sulzau $\left(89 \mathrm{~km}^{2}\right)$. For the latter gauge the percentage of glacierized area is $18 \%$. For these two sub-catchments the meteorological input data were used from the meteorological stations Krimml and Rudolfshütte, which are both outside the basin. For the large scale simulations the gauging station Mittersill at the river Salzach was used which has a percentage of glacierized areas of $6 \%$.

\section{Monitoring and field observations}

The Goldbergkees area has a long tradition in observing meteorological and hydroglaciological data. For the project SNOWTRANS the time period from 2002 to 2006 was considered for field measurements and modelling experiments. During that period several additional surveys were carried out. With respect to the needs of SNOWTRANS the following variables were monitored:

- Meteorological data (precipitation, air temperature, global radiation),

- snow depth (GPS tracks and satellite images),

- snow density and snow water equivalent,

- snow depletion

- ice and snow ablation

- glacier depth and glacier size,

- discharge and water levels (rating curves),

- stream water temperatures.

The monitoring work is documented in detail in Koboltschnig et al. (2006). In particular the observation period includes the very warm and dry summer season of 2003, where the snow cover totally depleted and intensive ice melt occurred. This effect is visible in figure 2, where the discharge measurements in 2003 clearly exhibit much wider amplitudes of diurnal runoff.

Hourly data of precipitation, air temperature, moisture, wind speed, sunshine duration and global radiation were taken from the observatory at the top of Hoher Sonnblick (Figure 1, Nr. 1). Three additional air temperature stations were installed during 2005 melt season at the basin area (Figure 1, Nr. 2, 3 and 4). A temporary tipping bucket, for liquid precipitation measurements only, was installed at the catchment outlet (Figure 1, Nr. 4). Water levels were recorded only between July and October, when the natural cross section of the glacial stream (in fact the lake outlet) is not affected by remaining snow or ice cover. The rating curves have been calculated for every melt season separately based on seasonal discharge (flow velocity) measurements. 


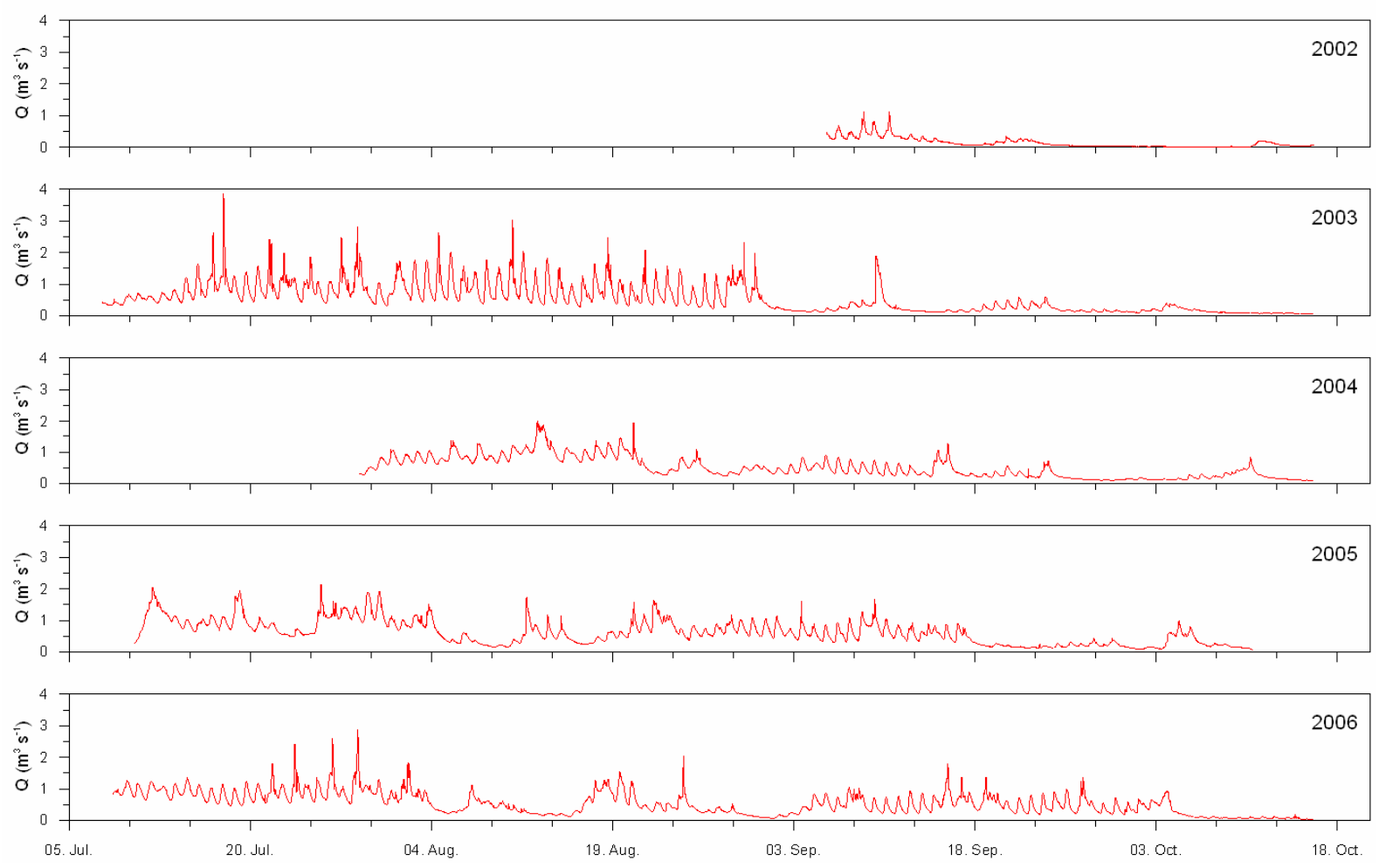

Figure 2: Discharge measurements 2002 - 2006 from Koboltschnig (2007a).

Snow depths have been measured automatically (by an ultrasonic sensor) at a daily interval close to the observatory (see Figure 1, Nr. 5). Starting with May 2005 four field campaigns for obtaining the spatial distribution of the SWE (snow water equivalent) of the catchment area were performed in a monthly interval. Therefore the snow depth was measured using aluminium probes at about 60 to 140 points distributed over the entire catchment area (see figure 3). The snow density has been measured in two to four snow pits following the instructions of Kaser et al. (2003). For the first campaign in May eight pits were dug because of the higher spatial variability of the snow density (Figure 1, grey triangles). From this very detailed data set we compiled distributed maps of SWE. Spline interpolation was applied to generate the snow depth distribution at a $10 \mathrm{~m}$ grid. The measured snow density data have been interpolated using inverse distance weighting technique and were multiplied by the distributed snow depth for computation of SWE. Snow depletion was mapped by means of simple GPS measurements and photographs. 


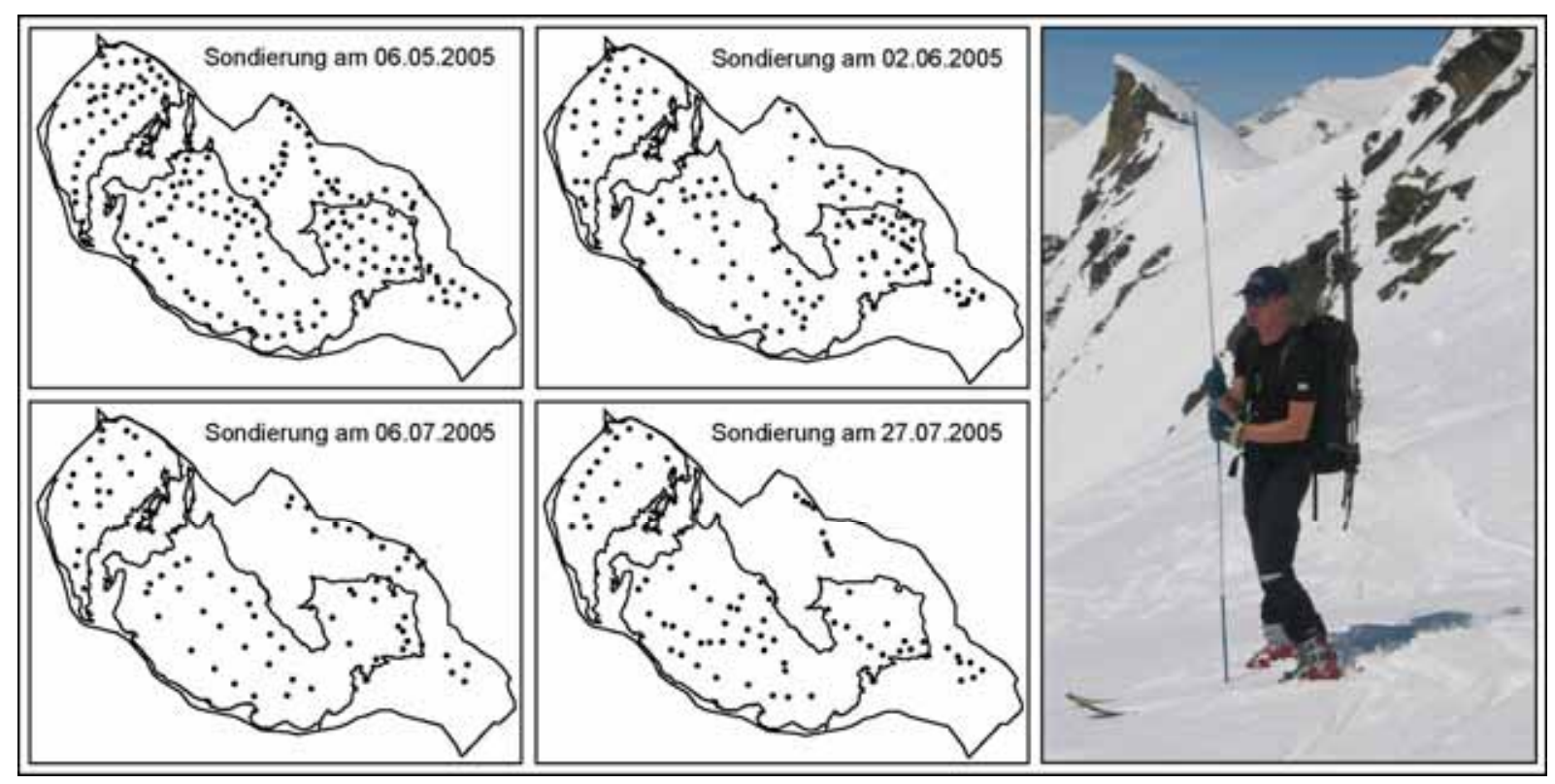

Figure 3: Snow depth courses for four dates in 2005 from Koboltschnig (2007a).

As part of the regular program of the mass balance investigations applying the glaciological method (Hoinkes, 1970; Østrem and Brugman, 1991; Kaser et al., 2003) the ice ablation has been measured using ablation stakes, which have been drilled into the bare ice of the glacier. Using 17 ablation stakes distributed over the entire ablation area of glacier Goldbergkees the net ablation of the glacier has been calculated (Hynek and Schöner, 2004). This data formed the base for annual and seasonal mass balance calculations, which provide an objective view on the retrieval trends of the glacier. Figure 4 shows the mass balance development during the last decades, where glacier Goldbergkees and two small glaciers in its vicinity were monitored. Most years exhibit a negative mass balance.

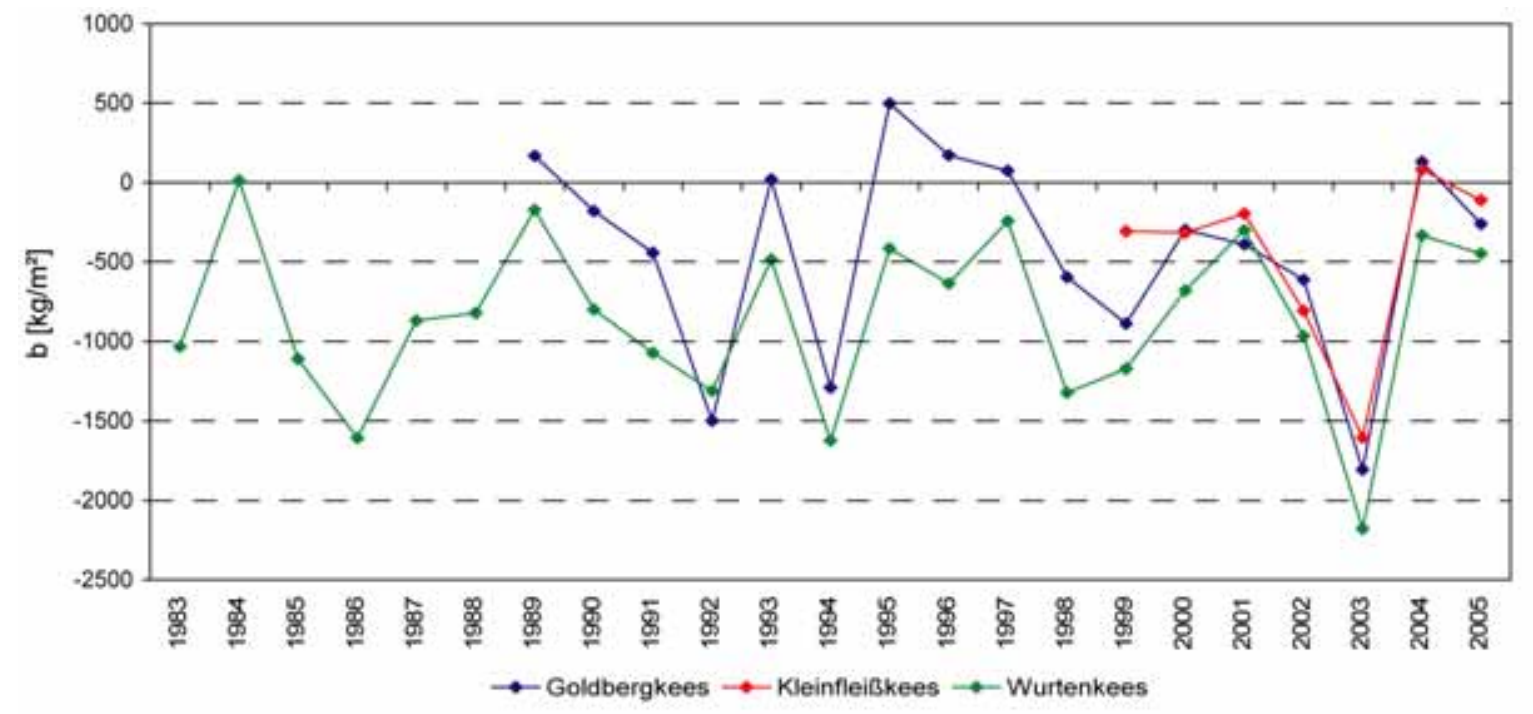

Figure 4: Annual mass balances of the glaciers Goldbergkees, Kleinfleißkees and Wurtenkees from Schöner \& Hynek (2006). 


\section{Modelling of Snow and ice melt processes}

For snow and ice melt modelling there exist a plenty of different methods and models. They can be classified roughly by distributed versus lumped models, energy balance models (physically based) versus index based models (conceptual), integrated models versus modular models. In the frame of the project SNOWTRANS three different model approaches were applied:

(a) Distributed index based model PREVAH (see Gurtz et al., Koboltschnig (2007a))

(b) Distributed energy balance model ALPINE3D (Lehning et al. 2006, Michlmayr, 2007)

(c) Semidistributed index model BOKU-Modell (see Holzmann (2006), Rauch(2007))

All models mentioned above were used for the Goldbergkees basin, as there exist the best data base of the meteorological driving forces due to the observatory. Temperature data were regionalized considering a lapse rate of $-0.0065 / \mathrm{m}$. Precipitation data were used with a correction factor of about $20 \%$ to count for the observation losses in high altitudes. Model (a) and (c) was additionally applied for catchments of bigger scales e.g. Obersulzbach $\left(19 \mathrm{~km}^{2}\right.$ resp. $89 \mathrm{~km}^{2}$ ) and Mittersill $\left(569 \mathrm{~km}^{2}\right)$. The temporal resolution of the models was 1 hour, where model (c) was also applied for daily time resolution.

\section{Application of PREVAH:}

PREVAH model is a distributed model based on the hydrotope or HRU concept. Hydrological similar units - defined by altitude, exposition and soil depth - are treated as a unique area, where snowmelt and runoff formation processes are aggregated and accumulated to the basin outlet. Interpolation of the meteorological boundary conditions can be done by an integrated preprocessing tool using GIS functionality. Computed state conditions can be visualized for single points as time series (snow depletion, total runoff, etc.) or for the entire basin as a map for a temporal snapshot (e.g. snow depth, soil water equivalence, annual balance).

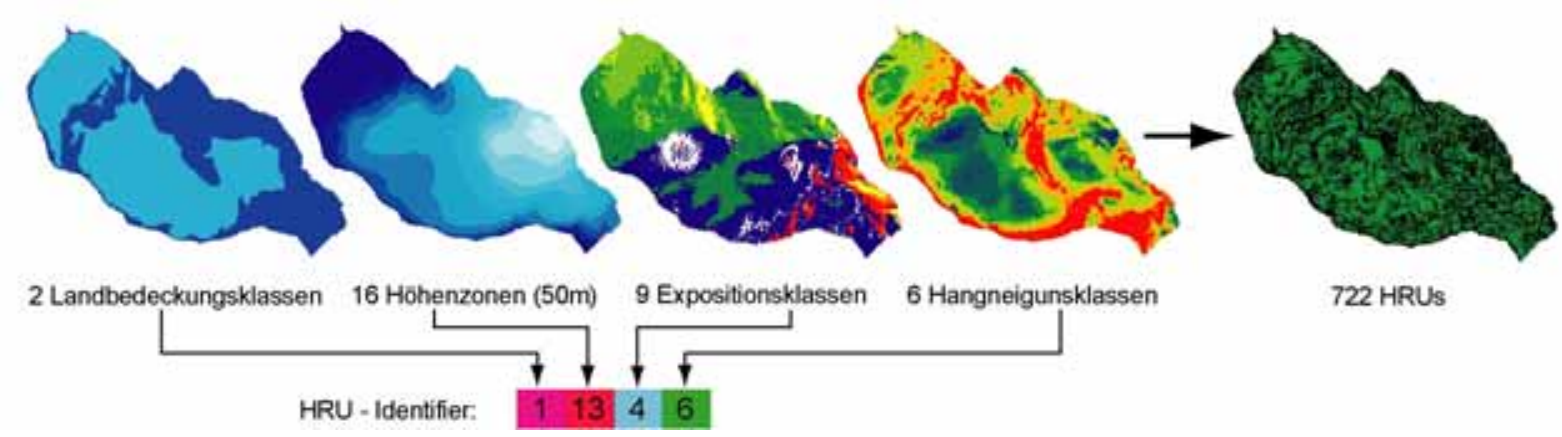

Figure 5 : Generation procedure for hydrological response units (HRU) based on land cover, elevation, exposition and slope from Koboltschnig (2007a).

The model PREVAH has been intensively applied by Koboltschnig (2007a) for different spatial scales. In his thesis he introduced a multiple validation approach where the model performance and reliability were tested by different observation data like snow depths observations at snow stakes, snow water equivalence for selected snow pits, surface discharge at the basin outlet or by areal snow cover data gained by remote sensing.

Regular hydrological applications tend to apply only runoff hydrographs for validation of models. But as the observed runoff is the integrative response of all hydrological components 
(like snow melt , ice melt, runoff from bare areas, baseflow etc.) it is not possible to identify spatial distributed parameter sets based on simple hydrograph comparison. Based on field monitoring programs several snow pit observations were interpolated for specific dates and thus provided spatially distributed state conditions. Figure 6 and 7 show the spatial patterns of simulated and observed snow water equivalent data as well as the average data of elevation bands. It can be seen, that the general pattern could be simulated by the model, but higher elevation zones tend to be overestimated where lower elevations are underestimated by the model. This is caused by snow drift processes due to wind and avalanches.
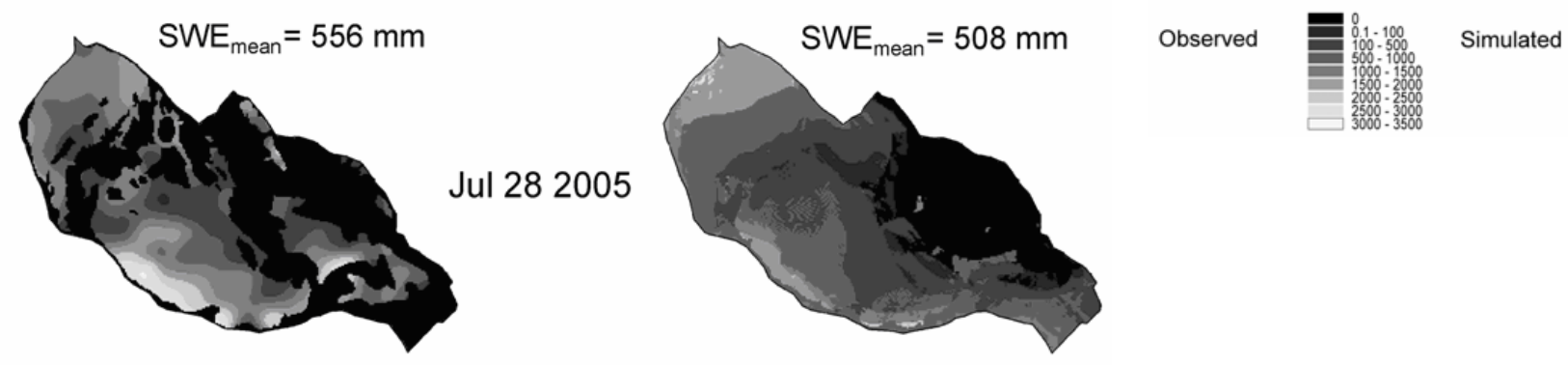

Figure 6: Spatial distribution of snow water equivalent (SWE) for Goldbergkees basin for July $28^{\text {th }}$ 2005. (From Koboltschnig, 2007a).
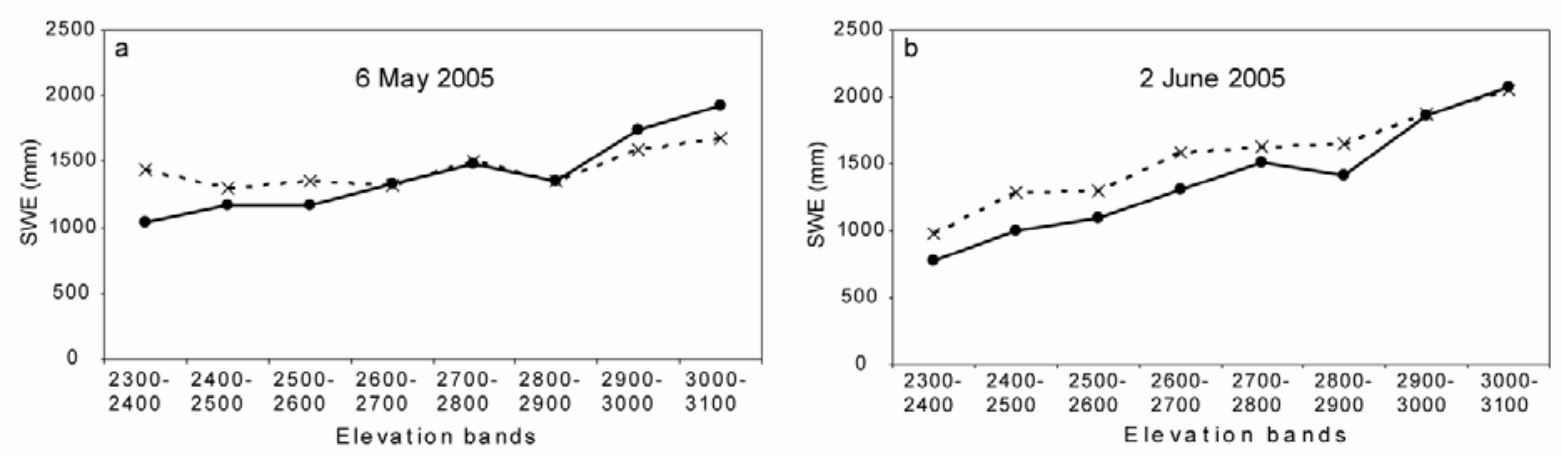

Figure 7: Comparison of observed (dotted) and computed (solid) snow water equivalent for 100-meter elevation bands. (From Koboltschnig, 2007a).

Snow water equivalent and snow depths exhibit a high spatial variety. Therefore spatial interpolation techniques tend to average the variations and lead to rather smooth pattern. The use of remote sensing data from satellite enables to show the true pattern of snow cover and temporal depletion respectively. Figure 8 shows the comparison between an ASTER image with the results of the distributed model PREVAH. 


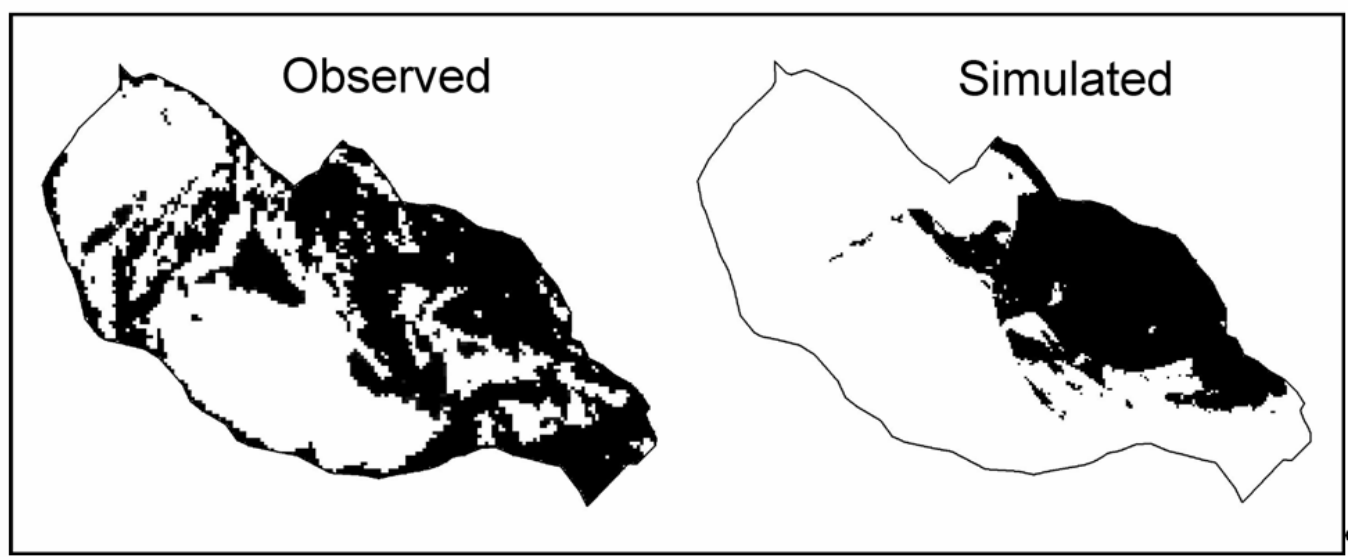

Figure 8: Simulated vs. observed snow cover pattern at 29 July 2005. The observed image is generated by a classification of an ASTER image. Black coloured areas indicate snow free areas, white areas are still snow covered. (From Koboltschnig, 2007a).

Runoff is the direct response to rainfall, snow and ice melt. As the test basin does not have any significant groundwater aquifer, the water balance can be listed as follows:

$$
Q=P-S+S M+I M \pm S T
$$

where $\mathrm{Q}$ is the runoff, $\mathrm{P}$ is precipitation $\mathrm{S}$ is snow accumulation, $\mathrm{SM}$ is snowmelt, IM is ice melt and ST is the subsurface storage (e.g. soil water storage). Ice melt contribution is only possible from areas without snow cover. The metamorphosis from snow to firn and ice is neglected in the above equation.

Where snow data (SWE, snow depth, depletion pattern) can be efficiently being applied for model parameter calibration, runoff data are preferentially used for fine tuning and validation of the model parameters. The aim is a reliable agreement both on accumulative runoff volume and on the temporal variety of the runoff. Figure 9 shows the high diurnal amplitudes which reflect the daily variety of temperature and radiation. The model performance for this period is quite good, the Nash-Sutcliffe accuracy is 0.6. The late summer runoff of September is slightly underestimated.

The estimated ice melt contribution could be validated by the glacier mass balance inventory, which was being done by the glaciology group twice a year (summer and winter balance). Results are given in Schöner \& Hynek (2006). 

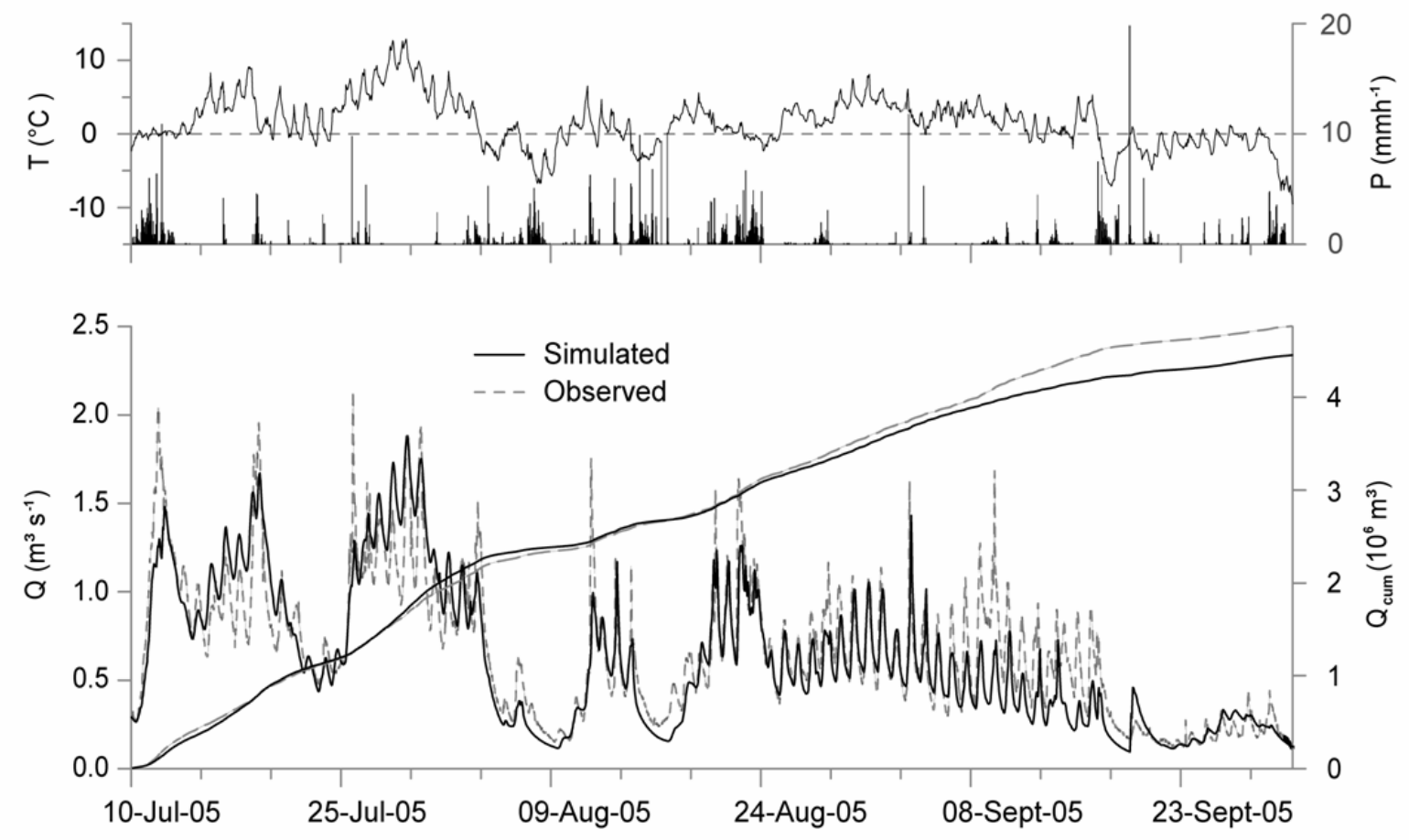

Figure 9: Comparison of observed and computed total runoff including precipitation and air temperature. (From Koboltschnig, 2007a).

\section{Application of ALPINE3D:}

Detailed simulations of the energy and mass balance of the snow cover and ice surface layer were done with Alpine3D model. A detailed description of Alpine3D can be found in Lehning et al. (2006). Its modular program architecture allows a good adjustment to the very specific conditions of a high Alpine study area. The different radiative fluxes, their interaction with the terrain surface, as well as their dependency on atmospheric conditions are taken into account as part of the energy balance module. Shortwave and longwave radiation is considered separately. The modelling of incoming global radiation includes separation into direct solar radiation and diffuse radiation, capturing different atmospheric scattering effects. Moreover reflection from surrounding terrain and shading effects are considered for radiation balance. For longwave radiation balance additional input from surrounding terrain or forest edges is considered by the model.

To calculate the influence of the surrounding topography on the radiative fluxes a view factor approach (Oke, 2000) is implemented into the energy balance module. The view factor of a point is the fraction of unobstructed sky which can be seen from this certain location. It is determined for each point of the model domain by processing a digital elevation model of the study area.

The necessary surface parameters to establish the radiation balance of a snow or ice surface are gained through a close coupling to the snowpack module (for a full description of the snowpack module see Bartelt and Lehning, 2002). Snow and ice bodies are described as a three-phase-material, consisting of ice, water and voids. Processes in other porous media such as soil or rock can be solved by the snowpack module in a similar fashion, by adapting the governing differential equations and the boundary conditions appropriately. 
The excess water from the snowpack module, as well as direct rain precipitation on blank rock surfaces are collected by a runoff module. The runoff at the catchment outlet is generated using a the conceptual hydrological model approach relying on the PREVAH model described above (Gurtz at al., 2003). The model was initialized for a continuous run of one year cycle starting from 22 September 2004 and ending in 30 September 2005. The temporal resolution of the computations is 1 hour. The study area is represented by a raster of $25 \mathrm{~m} \mathrm{x} 25 \mathrm{~m}$ grid domain. Initial conditions of the land surface had to be specified in a land cover mapping. Glacier extent was determined processing an aerial photograph from 2003. According to the inventory of 2004 Goldbergkees glacier was subdivided into three land cover classes: bare ice, firn and old snow. As the whole catchment lies above the vegetation line, considering the non-glacierized areas as rock surfaces is justified. A digital elevation model is further required to run the model. The model is forced by meteorological input data on an hourly base. For the current setting direct hourly observations of precipitation, air temperature, wind speed, global radiation, and relative humidity were used to operate Alpine3D. All data were obtained from measurements at Sonnblick observatory. Global radiation was redistributed using the energy balance module. For this study, precipitation, wind speed and relative humidity were assumed to be uniformly distributed over the study area, according to the observations from Sonnblick observatory.

For model evaluation a number of glaciological and hydrological observations were available: Six permanent snow stakes are located on glacier Goldbergkees, which are read on the first day of each month (Figure 1). Twice a year a glacier monitoring campaign is performed. To record the winter mass balance a large number of snow depth measurements using avalanche probes is done at the end of the seasonal accumulation period around beginning of May in addition to snow stake readings. Information about snow density and snow characteristics is gained from snow pits. The glaciological season ends at the beginning of October, which usually is the time of maximal ablation. At this date the annual mass balance is determined with a network of ice ablation stakes and a mapping of snow covered areas, which is performed in the same fashion as the measurements for winter mass balance. Hence twice each year a detailed description of the glacier mass changes in terms of water equivalent at a large number of sites is available (Hynek and Schöner, 2004).

By means of an interpolation procedure, using inverse distance weighting method (IDW) and a 3x3 mean value filter, spatial distribution of the water equivalent on the glacier can be obtained. During the melt season 2005 an intense ablation monitoring campaign was carried out. Changes of the glacier mass were recorded each month from May to August. The collected data give a detailed description of ablation patterns on the glacier and their temporal evolution during the melt period.

Since 2002 a runoff gauging station is operated at the basin outlet about $250 \mathrm{~m}$ downstream of the glacier tongue (Figure 1). The gauging station records water levels within the outlet continuously during the melt period.

The high availability of glaciological and hydrological observations in the study area made it possible to perform a multiple evaluation of the model results. Seasonal snow depth developments, which were derived from the snow stake readings, were compared with the modeled snow depths from the corresponding grid cells. The seasonal glacier mass balance changes were plotted against modeled snow and ice water equivalent (WE) changes. Mapping the differences between model result and observed values of the WE delivers insight into the spatial distribution of the quality of the results. 
A comparison of snow depth observations and the model results from the corresponding grid cells for the season 2004/2005 is presented in Figure 10. All snow stakes are located on the glacier. PG01 is situated on the glacier tongue. Only one stake (PG02) is installed on the middle part of the glacier, while four measurement points (PG03, PG04, PG05 and PG06) are maintained on the upper part.

The model simulates the snow depth development as interaction of precipitation, settling of snowpack and snowmelt. Influences from lateral processes like avalanches or wind deposition are not implemented in the current model setup. The precipitation is assumed to be uniformly distributed over the whole study area. Preferential deposition of snow, due to microclimatic conditions or topographical effects, is not taken into account either. The modelled snow depth curves show a very similar shape during the accumulation period from November to May. This is mainly a result of the uniform precipitation input. Larger differences among the single curves occur on the decreasing branch. An altitudinal dependency of modelled snow ablation can be discovered in the snow depth calculations of the six snow stakes. At all six locations the snow depth growth is slightly underestimated at the beginning of the season in November. During the second half of the accumulation period, from January to April the snow depth is overestimated by the model. Measured snow depth maxima, in most cases occurring at 1 May, show a good correspondence to the model results.

During the ablation period the differences between calculation and observation are small again. It can be seen that for locations on higher altitudes the results show an underestimation of snow depth. At lower points the snow completely disappears by the beginning of August. Related to the average measured snow depth the mean model error of all snow stake locations is $30 \%(42 \mathrm{~cm})$. Looking only at the ablation period (May-September) the relative average deviation between model result and observation is 18\% (34 cm). PG02, PG04 and PG05 have a relative error below 25\%. For PG03 and PG06 the model shows a weaker performance. Large errors occur between February and April. A snow depth decrease at the beginning of April at these locations possibly points to drifting snow events, which may be seen as reason for the gap between model result and observed value. Evidence for large drifting snow activities at these locations was also found by Mott et al. (2007a) for the season 2002/2003.

Figure 11 presents the total mass changes of the glaciological season 2004/2005. From measurements we find a slightly negative total glacier mass balance of $-0.220 \mathrm{~m}$ WE. During the annual period the glacier gained mass mainly in the uppermost parts and on its southern boundary. Mass losses could be observed on the glacier tongue and on the central plateau around PG02. The model results show a total mass balance of $-0.480 \mathrm{~m}$ WE. The model calculates major mass losses on the entire glacier tongue. The middle altitudes show a slightly negative WE, while at the uppermost areas around PG06 the mass balance remains positive. 

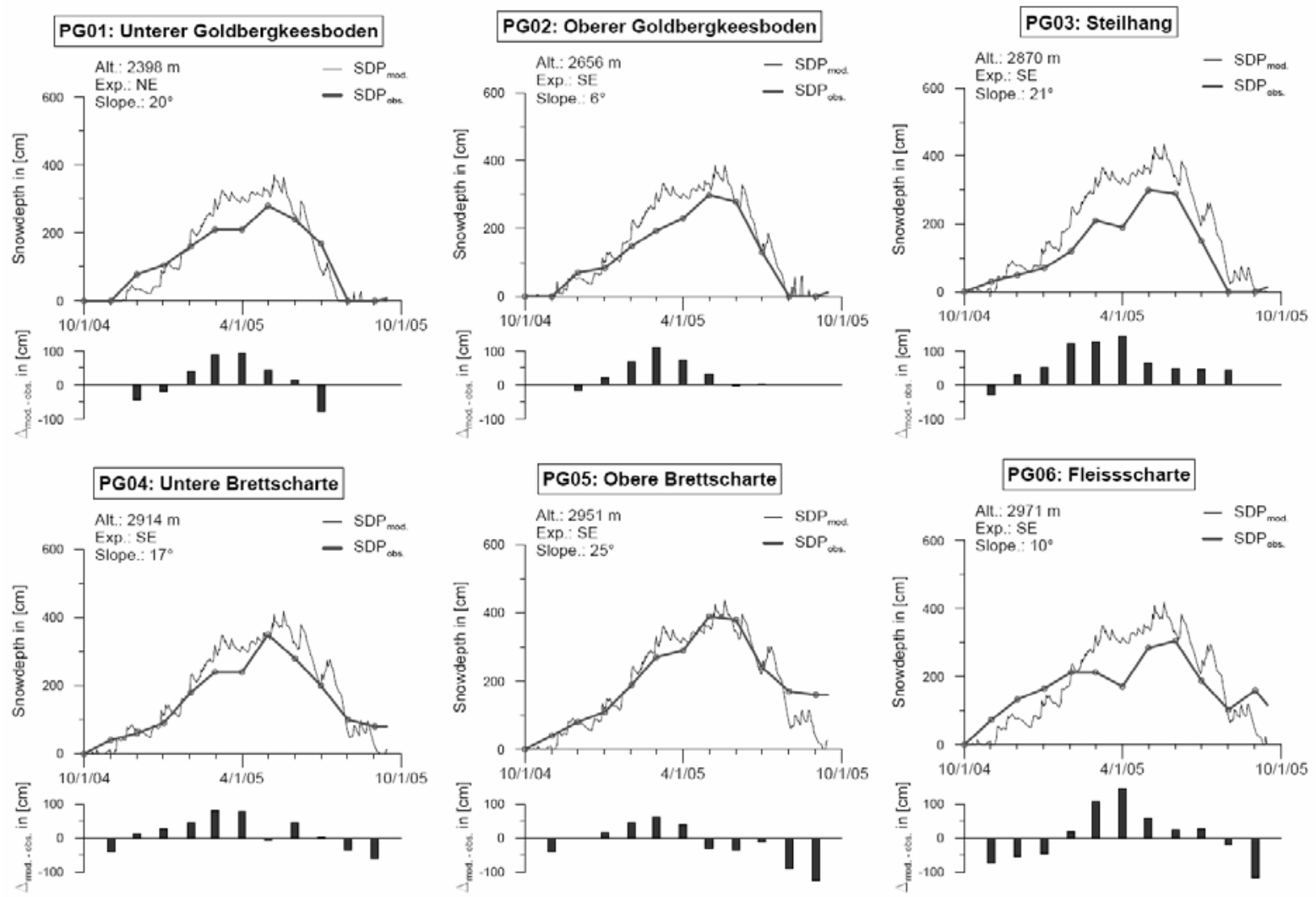

Figure 10: Snow depth development at the six different snow stake locations on the glacier. Daily modelled values are compared with monthly observations. (From Michlmayr, 2007).

Figure 12 shows a comparison of modelled and observed runoff data at the catchment outlet. Data from the discharge gauging station were available in 2005 from 9 July, to 30 September. A total cumulated specific runoff of $1763 \mathrm{~mm}$ was recorded during this period. At the beginning of the melt season the discharge curve shows strong fluctuations with single peaks of more than $2.5 \mathrm{~mm} / \mathrm{h}$ related to high snow melt contribution. After two cold periods in August, leading to low runoff rates, the influence of strong snow melt events decreases. Melting ice becomes more important as source for water discharge. During warm season a distinct water drainage system through the glacier ice develops and the effect of snow and firn storages decrease (Jansson et al., 2003). Correspondingly the mean discharge rate decreases to a lower level and the fluctuations show a more constant diurnal characteristic with a smaller amplitude. The modelled cumulated specific discharge during the runoff season amounts to $1890 \mathrm{~mm}$. At the beginning of the evaluation period the diurnal extremes of the modelled discharge are overestimated. Daily minima are slightly underestimated while the runoff peaks are overestimated. 


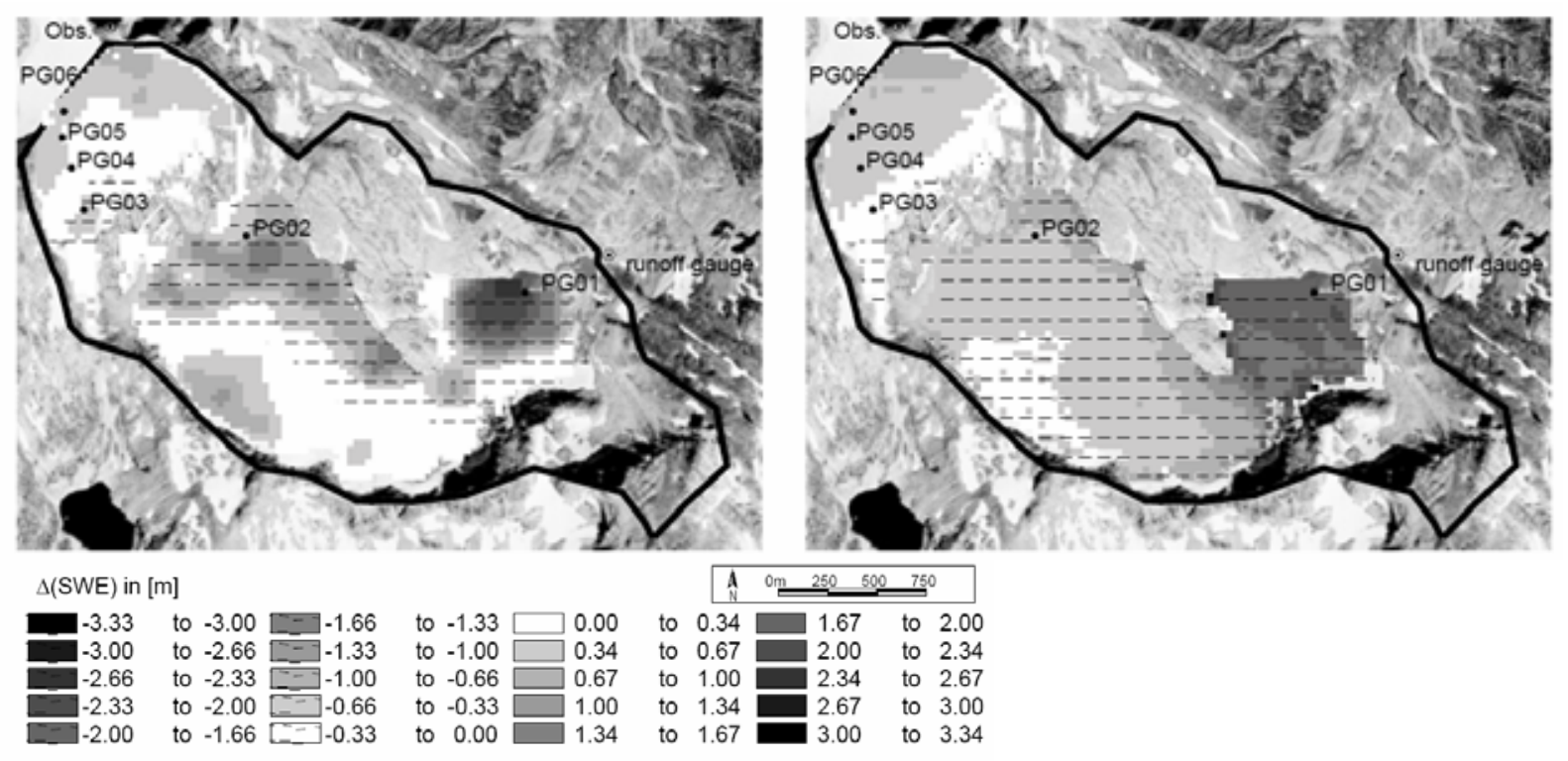

Figure 11: Total mass balance of Goldbergkees for the glaciological season 2004/2005 in terms of water equivalent (WE); comparison of modelled and observed values. Histograms show the WE distribution over the computational grid (modelled and observed). (From Michlmayr, 2007).

Mean runoff rates are captured well by the model. Deviations between model results and observations tend to decrease during the course of the melt season, which presumably is linked to the development of steady glacier storage. The model efficiency after Nash Sutcliffe (Nash and Sutcliffe, 1970) for the runoff simulation is 0.56, the explained variance number reaches a similar value of 0.57 . The small difference between both measures speaks in favour of a negligible systematic failure of the simulated runoff rates. To avoid an overrepresentation of peak runoff errors in the efficiency measures, Nash Sutcliffe model efficiency and explained variance were also plotted for logarithms of discharge rates. Likely the values of $\operatorname{logNS}-\mathrm{ME}$ and $\operatorname{logEV}$ reach a higher value of 0.75 . Because of the small catchment size and water transported predominantly in sub surface, therefore flow routing retention was neglected. Maximal model efficiency at a time shift of 0.0 hours supports the assumption, that no additional storage effect influences the runoff curve. 


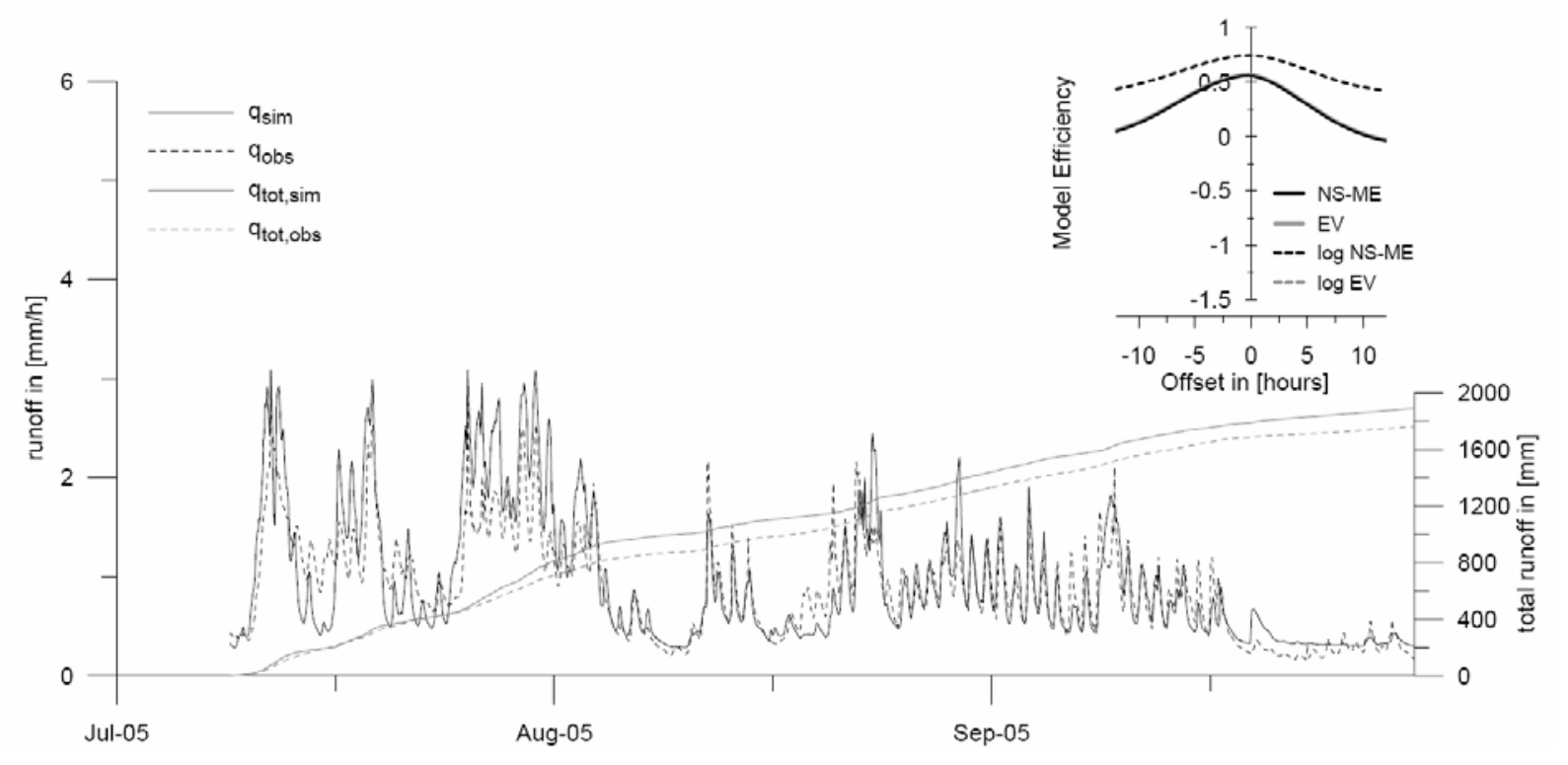

Figure 12: Evaluation of the runoff simulation. Dashed lines represent observed data, solid lines indicate modelled values. Nash-Sutcliffe Model Efficiency and Explained Variance number of the hourly discharge simulations are shown in the top right chart. Efficiency measures were also calculated for shifted model results (+/- 12 h) (From Michlmayr, 2007).

\section{Application of BOKU-Modell:}

The Institute for Water Management, Hydrology and Hydraulic Engineering (IWHW) of the University of Natural Resources and Applied Life Sciences Vienna (BOKU) developed several program routines for snowmelt and snow accumulation. Due to the aims of different projects the spatial and temporal resolutions varied within a broad range. Kling et al. (2004) applied snowmelt for monthly water balance analysis based on $1 \mathrm{~km}^{2}$ grid. Holzmann \& Nachtnebel (2000) developed snowmelt routines with daily time resolution and 500-meter elevation bands for runoff forecast of entire Austria. Habersack et al. (2005) applied snow and ice melt routines for the assessment of glacier runoff contribution for a medium basin of 590 $\mathrm{km}^{2}$ under dry conditions. For applicability for small basins Holzmann (2006) adopted the model for hourly time resolution and 100-Meter-elevation zones.

In the frame of the project SNOWTRANS some model updates with consideration of albedo, cold content and subgrid variability of exposition were carried out by Holzmann (2006). Rauch (2007) tested the updated version for the Goldbergkees basin, where Holzmann (2007) applied it for a $20 \mathrm{~km} 2$ basin (Obersulzbach, gauge Kees) in combination with a conceptual runoff model considering subsurface interflow in moraines.

The snowmelt procedure is based on a mixed index approach with consideration of air temperature and global radiation. These data were observed at the observatory of Sonnblick. 


$$
M_{i, k, j}=\alpha \cdot T I_{k} \cdot \operatorname{Temp}_{i, j}+(\alpha-1) \cdot R I \cdot \operatorname{Rad}_{i}
$$

$$
\begin{array}{lll}
\text { where } & \text { M } & \ldots \text { snowmelt rate }(\mathrm{mm}) \\
\text { TI } & \ldots \text { temperature index } \\
\text { RI } & \ldots \text { radiation index } \\
\text { Temp } & \ldots \text { positive air Temperature } \\
\text { Rad } & \ldots \text { Global Radiation } \\
\text { k } & \ldots \text { seasonal Index } \\
\text { i } & \ldots \text { temporal Index } \\
\mathrm{j} & \ldots \text { elevation index } \\
\alpha & \ldots \text { weighing factor of temperature }
\end{array}
$$

The right hand term of equation 2 can be expanded by the following product considering albedo, cold content and subspace variability of exposition

$$
\operatorname{albfak}_{i, j} \cdot \text { ccfak }_{i, j} \cdot \operatorname{exfak}_{j}
$$

The albedo factor considers increased reflection of radiation due to fresh fallen snow. It is estimated by the following equation

$$
\operatorname{albfak}_{k}=1-\exp \left(\frac{- \text { idayalb }_{k}}{\text { fakk }}\right)
$$

$\begin{array}{lll}\text { where: } & \text { albfak } & \text { albedo factor } \\ \text { idayalb } & \text { age of fresh fallen snow (in days) } \\ \text { fakk } & \text { recession factor (default }=4.0) \\ k & \text { elevation index }\end{array}$

The cold content factor takes into consideration, that the snow column requires some preliminary energy input to enable melting. It is computed as follows:

$$
\operatorname{ccfak}_{j}=\sum_{k=1}^{-n} \text { tempref }_{k}+\left(\text { hypsgrad } \cdot\left(\text { gebalt }_{j}-\text { altref }\right)\right)
$$

$\begin{array}{lll}\text { where: } & \begin{array}{l}\text { ccfak } \\ \text { tempref } \\ \text { hypsgrad } \\ \text { gebalt } \\ \text { altref }\end{array} & \text { cold content of elevation } \mathrm{j} \\ & \text { reference temperature } \\ & \text { lapse rate } \\ & \text { mean elevation in zone j } \\ \text { elevation of reference gauge }\end{array}$

In the snow melt model elevation bands are treated as homogeneous areas. In fact we can observe different expositions within the bands leading to different potential melt rates. Therefore a GIS based analysis for classification of the distribution of the expositions within a particular elevation band was applied. North faced expositions were assumed to have minor melt rates where south faced expositions were considered by increased potential melt rates as follows:

$$
\text { exfak }=\frac{1}{100} \bullet \sum_{K=1}^{9} \text { exarea }_{k} \bullet \mathrm{ff}_{k}
$$

$\begin{array}{lll}\text { where: } & \text { exfak } & \text { exposition factor of elevation band } \\ & \text { exarea } & \text { areal content of exposition class } k \text { (in percent) } \\ & \text { weighing factor of exposition class } k \\ k & \text { index of exposition class (1 to } 9)\end{array}$

The weighing factors varied from 0.7 (north facing) to 1.5 (south facing) and were estimated by calibration. 
The applied snow melt method provides a direct runoff response signal, which has to be transformed to the basin outlet. Due to the small size of the test basin a linear storage assumption was sufficient, subsurface storage was neglected. Three parallel storages for rain, snow melt and ice melt were defined. Three (hydrological) years from 2003 to 2005 were simulated.

Rauch (2007) compared temperature index, radiation index and the above described mixed index approach. The latter provided the best model performance. The parameter sets gained by calibration are listed in his diploma thesis. The validation of the model was done by use of discharge time series, snow depths and snow water equivalent (SWE) data at single observed snow stakes and SWE for different elevation bands. Hourly discharge comparisons gave correlation coefficient of 0.85 (year 2003) and 0.89 (year (2005).

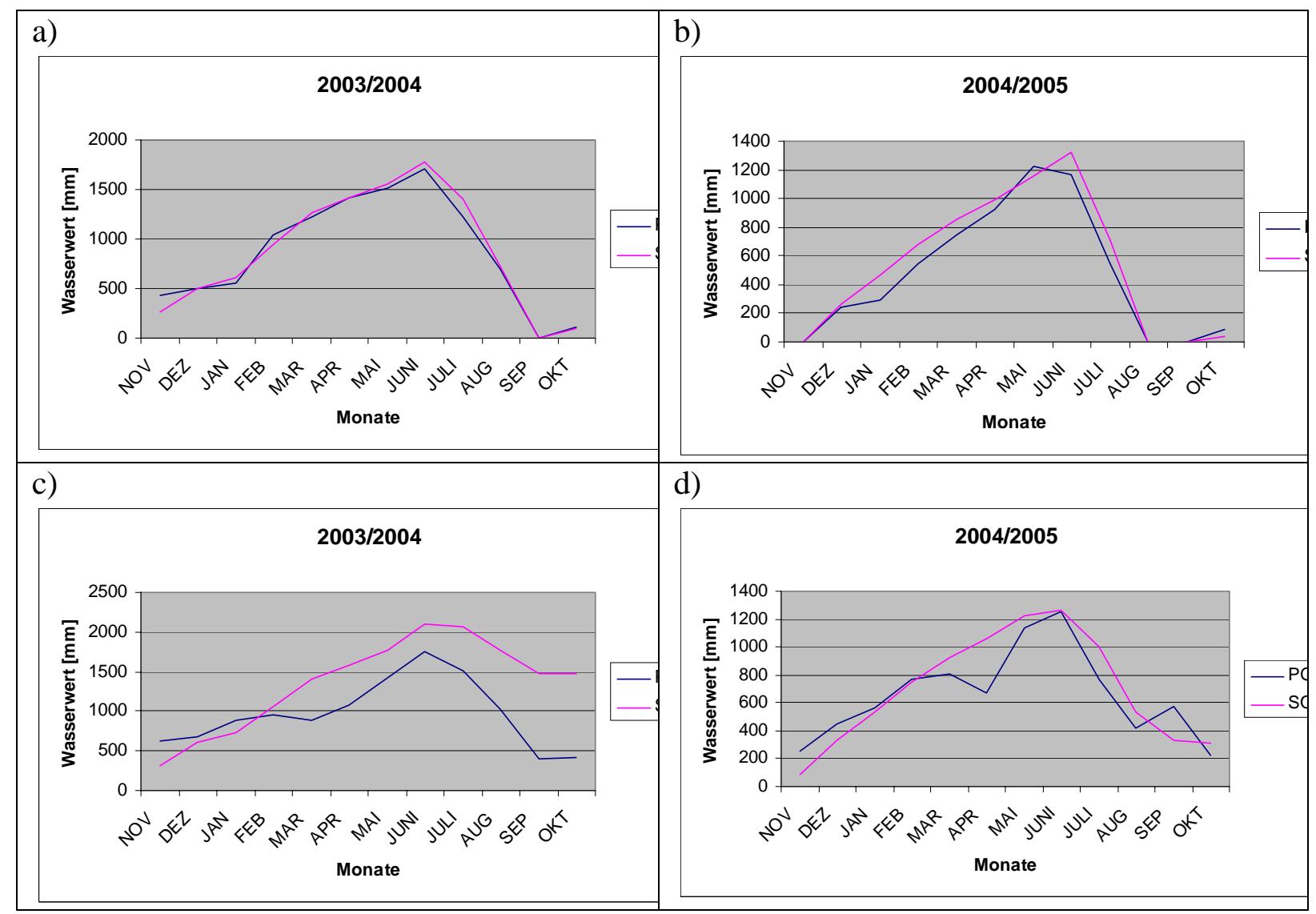

Figure 13: Comparison of observed (dark blue) and simulated (red) snow water equivalence in mm for snow stake PG2 a), b) (2650 m a. sl) and for snow stake PG6 c), d) (3050 m a.sl.) (From Rauch, 2007).

Figure 13 shows the comparison of simulated and modelled water equivalence values for the meteorological period 03/04 and 04/05. The results agree very good for the mean elevated snow stake located in $2650 \mathrm{~m}$ a. sl. Both the accumulation and depletion phase were simulated excellently. The values for the peak area (3050 m a sl.) are not so sufficiently modelled. Especially for the period 03/04 the model could not completely melt the accumulated snow cover, where the real snow cover depleted until September. Overestimations of the accumulation may be caused on the missing snow drift assumptions in the model. 


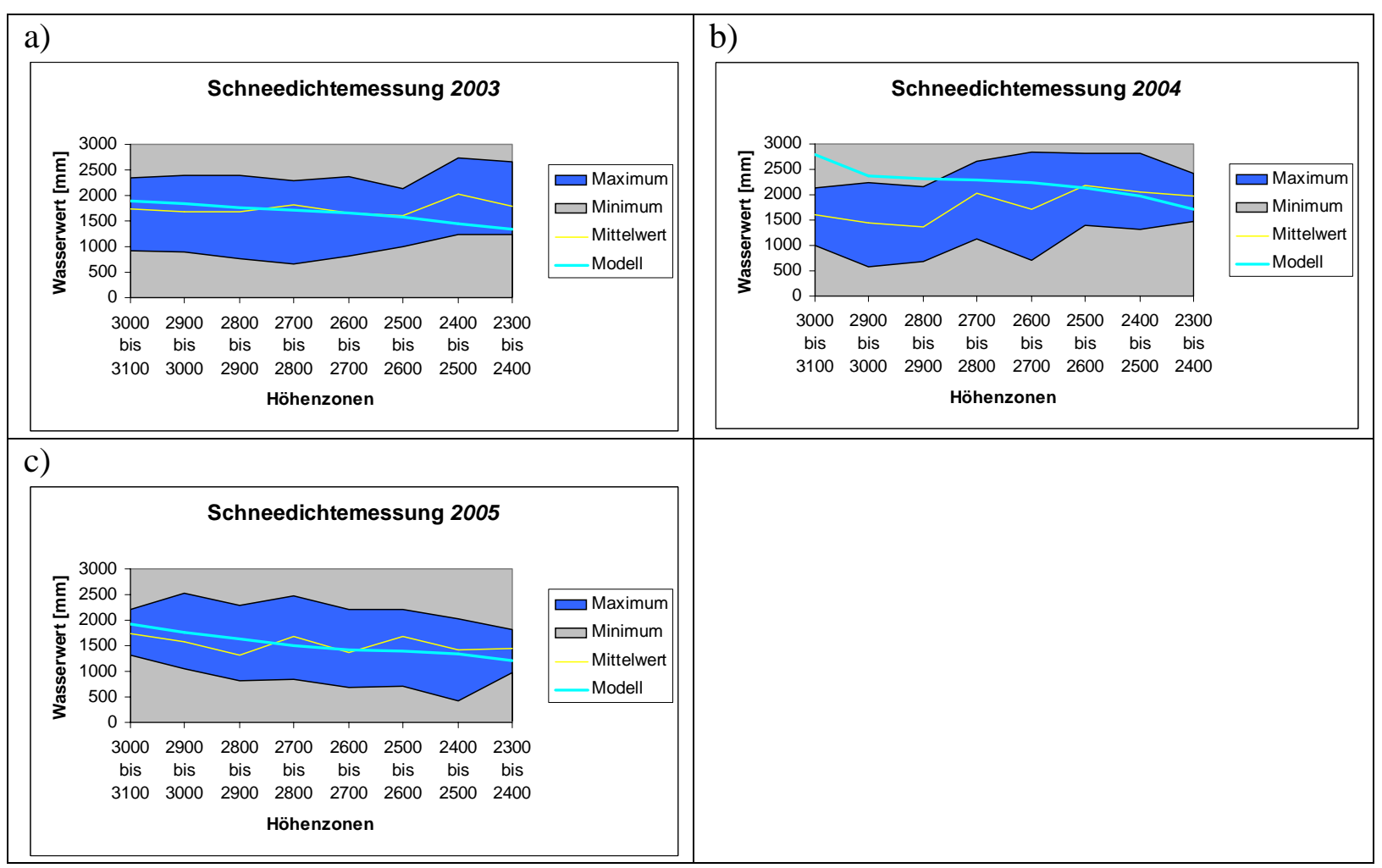

Figure 14: Comparison of observed snow pit data and simulated (bright blue) snow water equivalence in $\mathrm{mm}$ for the whole elevation range (From Rauch, 2007).

Figure 14 compares the modelled water equivalence of the computational elevation bands (100 Meter) with probe observations in the correspondent zones, indicated by a range of values (blue bands). For the years 2003 and 2005 the simulations lay in the range of the observations and show good agreement with the mean values. The computations for the year 2004 exhibited significant overestimations for the higher elevation bands 2800 to $3100 \mathrm{~m}$ a. sl. Generally the snow accumulation tends to be overestimated for higher altitudes and underestimated for the lower areas. Again the reasons are interpreted as snow drift processes.

Mixed Index Method / Linear Storage - August 2003

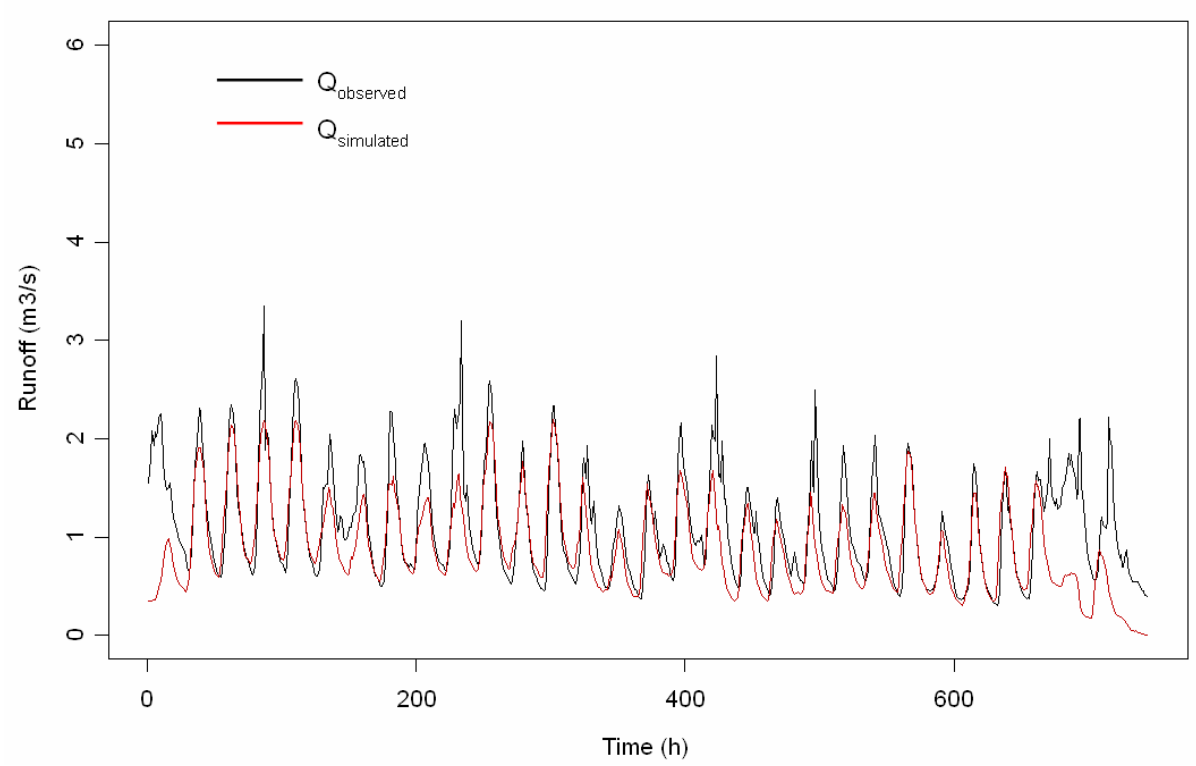

Figure 15: Comparison of observed and simulated discharge for Goldbergkees (From Holzmann, 2007). 
The validation based on the runoff hydrographs (see fig. 15) showed good results regarding the diurnal fluctuations and the temporal occurrence of peaks. The absolute values of the peaks were slightly underestimated by the model. The best results were gained by the mixed index model considering both temperature and radiation.

Contrary to the experiences at Goldbergkees the melt and runoff modelling results for gauge Kees at the Obersulzbach valley $\left(19 \mathrm{~km}^{2}\right)$ showed, that the runoff transformation by a simple linear storage is not sufficient for this basin scale. Figure 16 exhibits a significant stagnant baseflow in the discharge records superposed by the melt signal during daytime. The standard procedure described above underestimated the runoff during nighttime.

Mixed Index Method / Linear Storage - August 2003

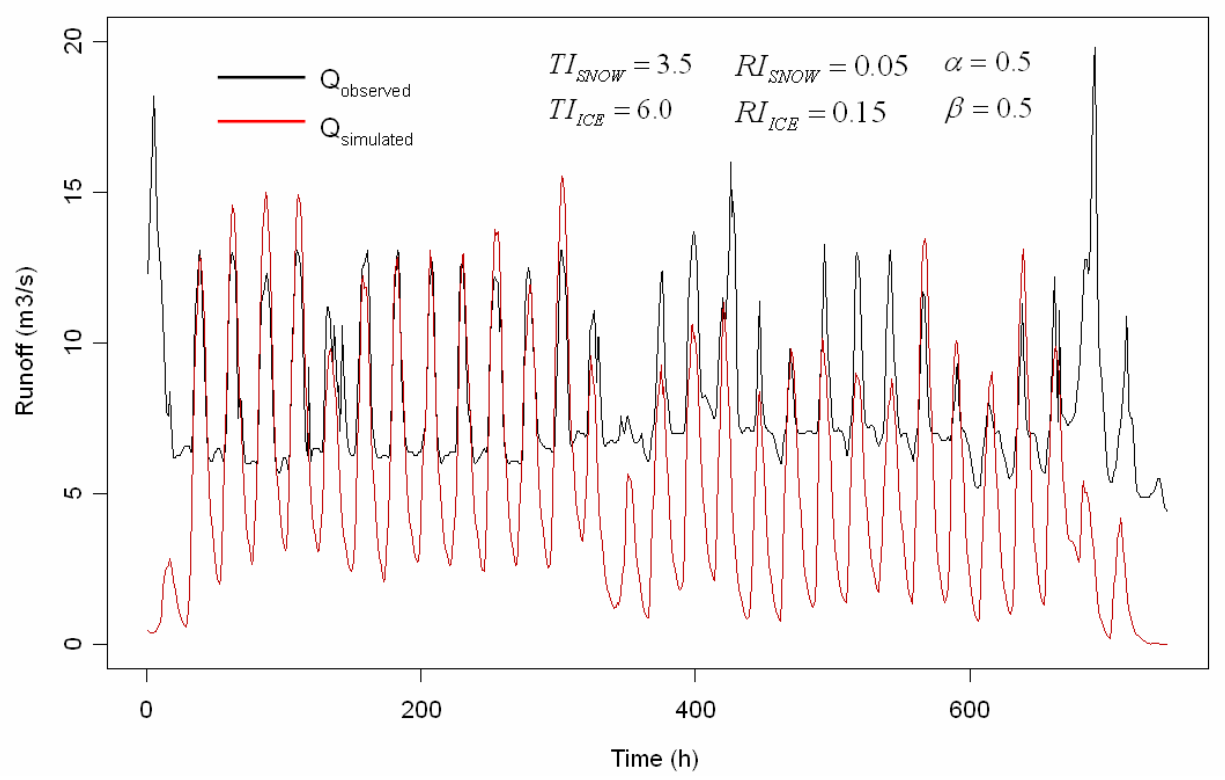

Figure 16: Comparison of observed and simulated discharge for Goldbergkees (From Holzmann, 2007).

Therefore the linear storage transformation was substituted by the application of a conceptual rainfall runoff module (see Holzmann et al. 2000). The melt rates as the driving input for the period August 2003 were subdivided into a quick runoff through linear storage and a delayed subsurface runoff in sediment or moraines. The runoff pattern of the entire melt period of 2003 can be seen in figure 17. The red line represents the subsurface component, where the blue line corresponds to the total simulated melt rate (baseflow plus surface melt flow). It can be seen that the seasonal pattern could be simulated quite reliable. 


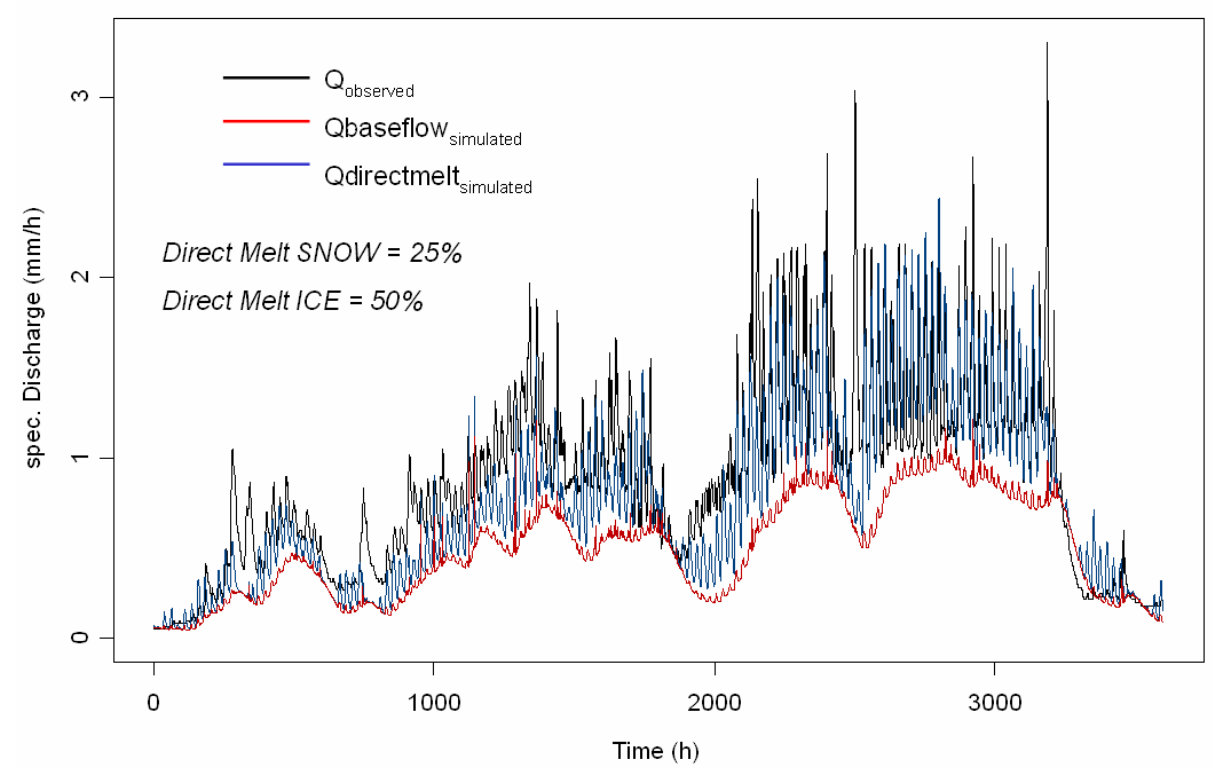

Figure 17: Comparison of observed and simulated discharge for gauge Kees (Obersulzbach) (From Holzmann, 2007).

At the start of the melt period the early melt rates where a little bit underestimated and leads to the conclusion, that the snow accumulation during winter 02/03 was also underestimated. The detailed graph of the month of August (figure 18) shows a satisfying agreement between the simulated and observed runoff. The direct, quick runoff of snow melt was $25 \%$ and $50 \%$ of ice melt respectively. The complementary quantities were assumed to be infiltrated into the subsurface.

Water Balance Model - August 2003

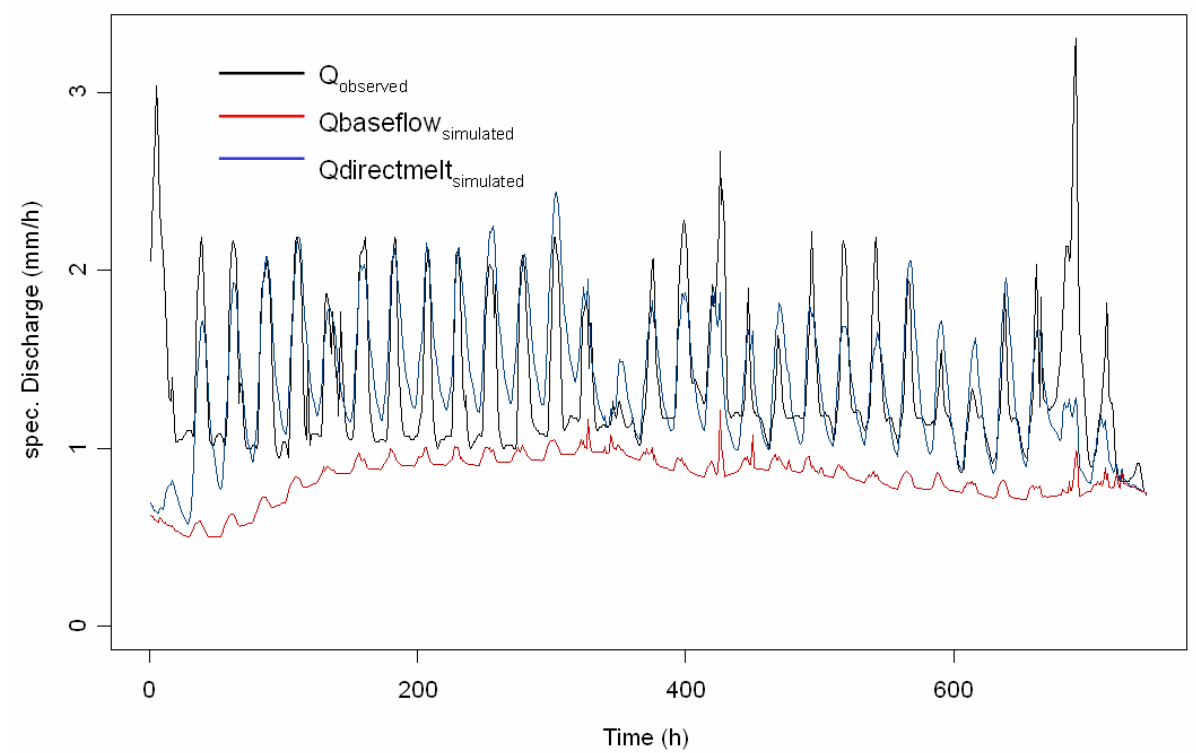

Figure 18: Comparison of observed and simulated discharge for gauge Kees (Obersulzbach) August 2003 (From Holzmann, 2007). 


\section{Modelling of snow drift}

Snowdrift is one of the major factors influencing seasonal snowcover distribution on glaciers. For mass and energy balance research, it is important to know the amount of redistribution of already deposited snow due to snowdrift as well as the preferential deposition of snow during snowfall events on glaciered areas. The investigation focused on modelling typical seasonal accumulation and ablation patterns as well as the distributed snow cover development on two alpine glaciers, the Goldbergkees and Kleinfleisskees, located in the Austrian Alps (see Mott, 2007a and Mott et al. 2007b).

High resolution wind fields over the complex topography of the Rauriser Sonnblick area were computed with the mesoscale atmospheric model ARPS (Advanced Regional Prediction System). One example for the spatial wind velocity distribution is shown in figure 19 (see Mott 2007 a). The calculated wind fields were used as input for the three dimensional model of drifting snow within the coupled physically based, distributed snowpack model Alpine3D, which has already been described in the section above. The influence of terrain effects on the snow surface energy balance were taken into account with a 3D energy balance module. Furthermore the threedimensional model is coupled with the one-dimensional heat and mass balance model SNOWPACK, describing the evolution of snow covers and snow cover characteristics. Validation of the simulated snow-depth distribution were done using monthly snow stake readings at six different locations in the basin, seasonal snow profiles (snow layers, snow temperature) and winterbalance maps presenting the distributed snow depth measurements at the end of the accumulation season 2002/2003.

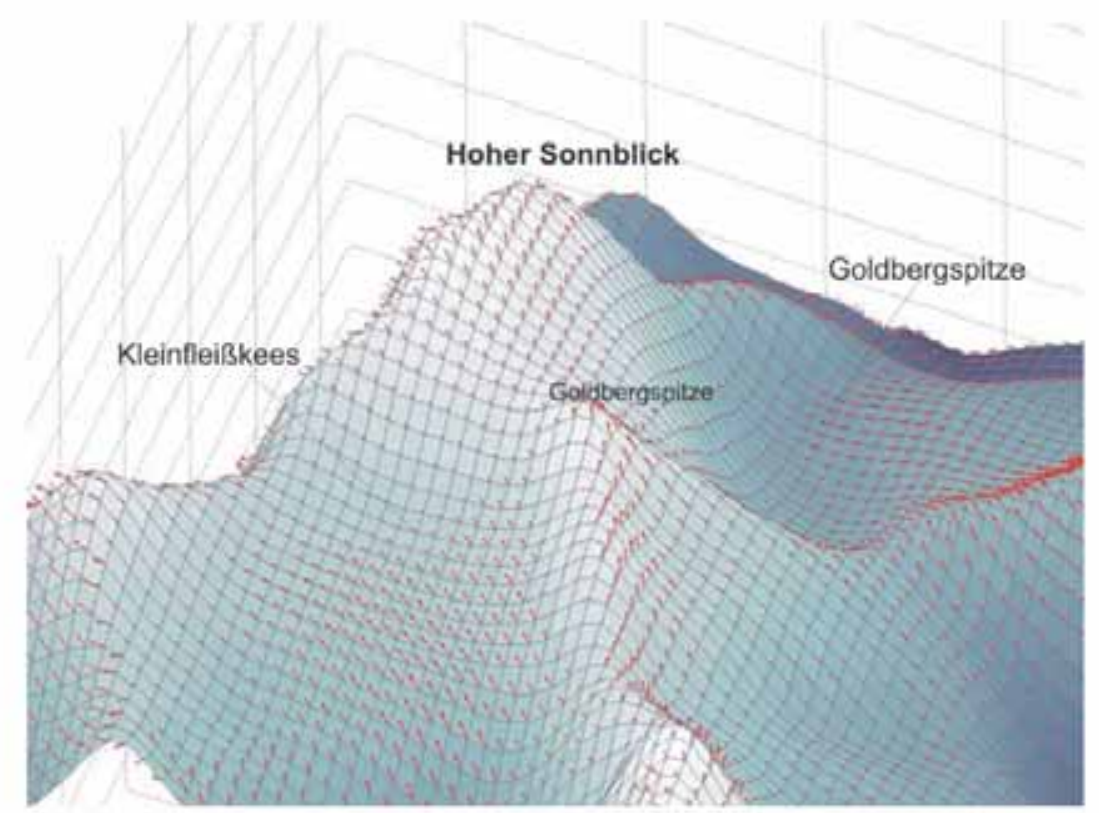

Figure 19: Distribution of nearsurface wind velocities for westwind conditions (From Mott, 2007a).

The model results are focused on (1) modelled flow fields during the accumulation period, representing the influence of the main wind characteristics and their potential contribution to the seasonal snow depth distribution; the flow fields show realistic features of acceleration, flow deflection and flow separation; (2) influence of the redistribution of already deposited snow due to snowdrift events; these results show the amount of drifted snow due to saltation processes and suspension during drift periods; (3) potential accumulation areas due to preferential deposition during snowfall events with moderate wind speed (see figure 20); (4) 
the seasonal snow cover distribution of the accumulation season winter 2002/2003. The model results from this section work could potentially be used as improved state conditions of snow cover.

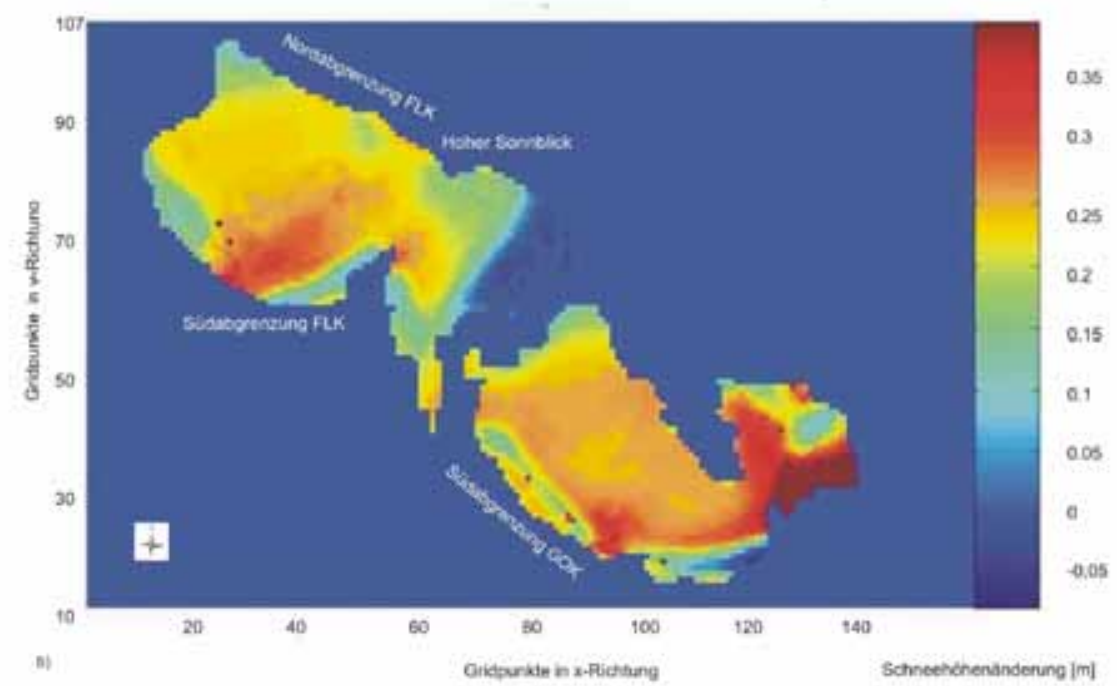

Figure 20: Snow depth redistribution for westwind conditions during $24 \mathrm{~mm}$ snowfall event. (From Mott, 2007a).

Considering the complexity of the model the spatial patterns of erosion and accumulation were generally simulated with quite high accuracy by the Alpine3d model for the most parts of the two glacier basins. As a result of the spatial variability of the drift processes the spatial distribution of the snow cover is well recognized by the model. Snow drift processes have a strong impact on snow cover development in regions of strong accumulation and erosion. Basically the allowance of drift processes, at least by using conceptual approaches, has to find its way into index based snow cover modelling in the future.

\section{Remote sensing}

The aim of the subproject "Remote Sensing" is to exploit the possibilities of remote sensing to acquire data on the type, on the areal extent and on the patterns of snow and ice cover in the catchment basins under examination at different stages of snow depletion as input information for hydrological models. In particular, the following questions were to be studied:

(a) How far is it possible to distinguish fresh snow, firn (corn snow) and ice on remotely sensed images?

(b) How far is it possible to obtain time series of snow depletion patterns from satellite images?

The study is restricted to optical remote sensing (excluding microwave techniques). The information content and the significance of remotely sensed image data is described by various forms of "resolution", amongst others by the spatial resolution (describing the degree of geometric detail to be obtained with the images), the spectral resolution (describing the suitability of the data to distinguish different materials or types of land cover) and the temporal resolution (describing the time interval between acquisition of consecutive images and thus the suitability of the image data to compile time series). For technical and for economic reasons, it is not possible to have one single sensor of high spatial, high spectral and high temporal resolution. Data from different sensors have to be combined. The study 
concentrates on the use of image data of type Landsat (Landsat TM and ETM+ and ASTER) (combining medium spatial resolution, medium spectral resolution and affordable costs) and of MODIS image data (offering a combination of highest temporal resolution and very good spectral resolution free of charge for research purposes).

The study described in this chapter was done in a diploma thesis by Markus Vollmann. The literature survey and the methods described here can be found in more detail in this thesis (see Vollmann, 2007).

\section{Spatial subpixel analysis:}

The method works on the digital numbers of the image representing radiance or reflectance. For this purpose, the remotely sensed real-world objects are described locally (for a certain pixel and its neighbourhood) by a geometrical-physical model. This model contains a set of parameters describing the object's geometry and pure spectral signatures.

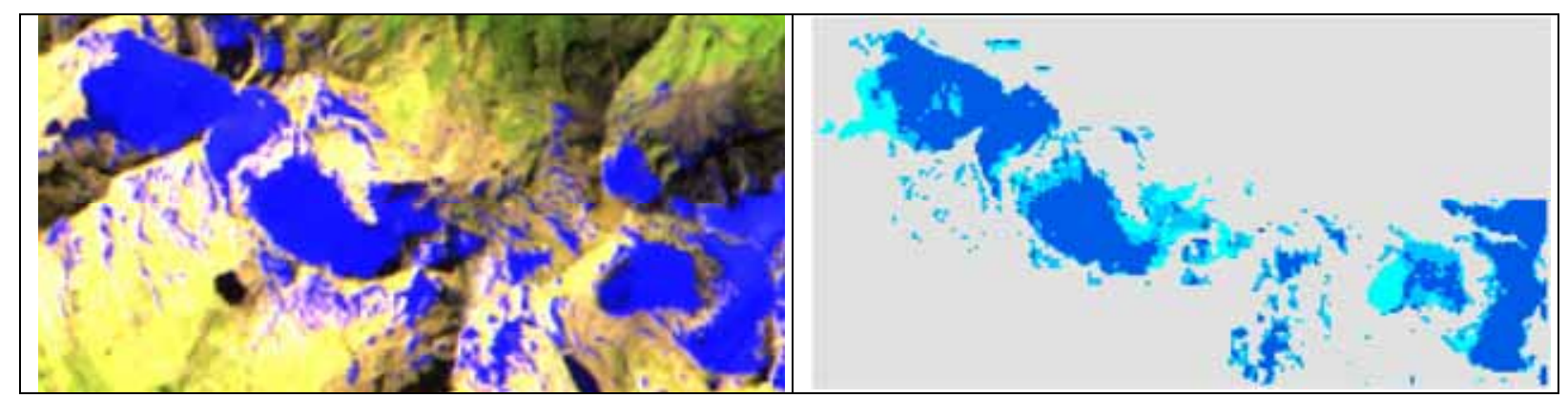

Figure 21: Goldberg-Gruppe: Snow- and ice-map Landsat image (bands 7-5-2 in R-G-B) of 12. 8. 1993. from (Kaiser et al., 2007)

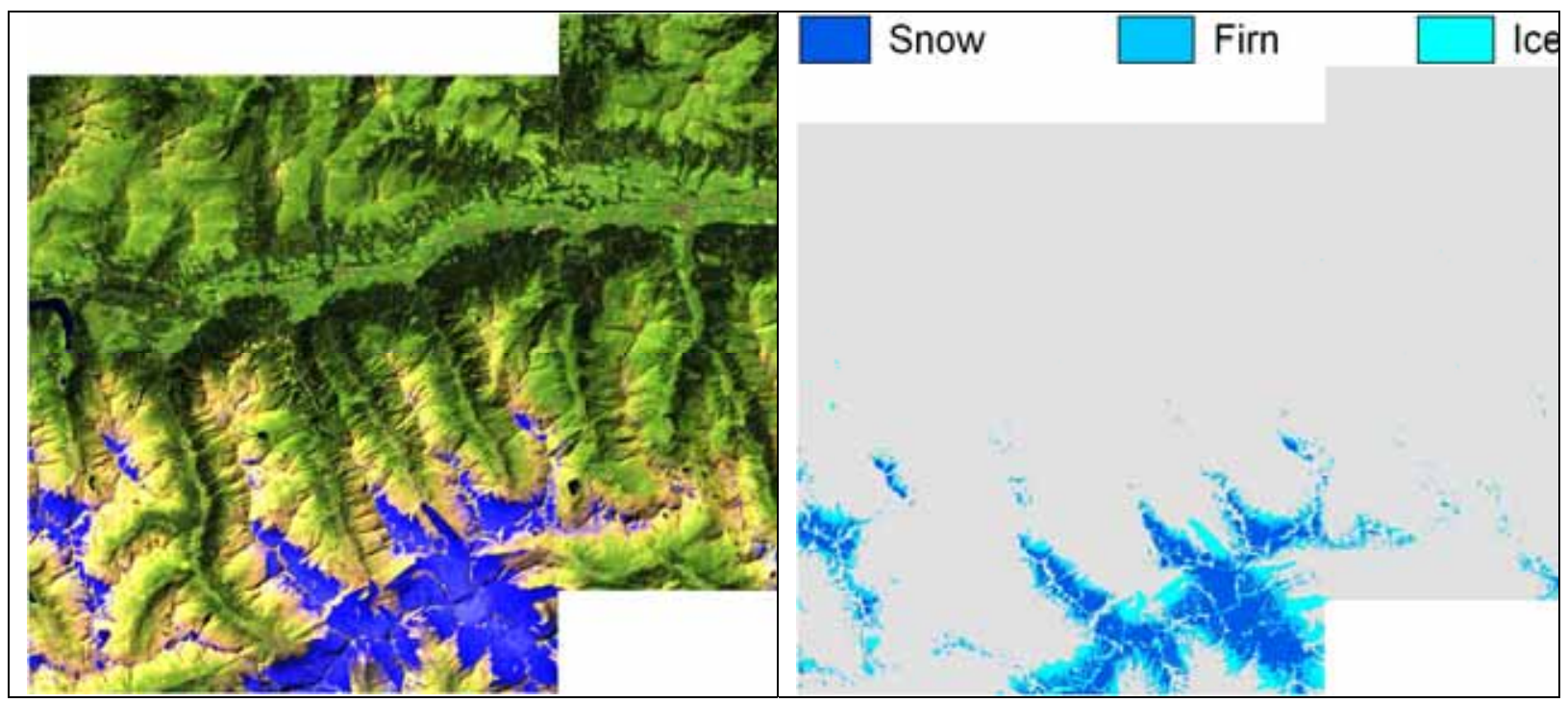

Figure 22: Mittersill: Snow- and ice-map ASTER image (bands 5-4-1 in R-G-B) of 10. 9. 2004. from (Kaiser et al., 2007)

The figures 21 and 22 give examples of Landsat and Aster images and the correspondent interpretation of the analysis with respect to snow, firn and ice classification.

A prerequisite for successful functioning of spatial subpixel analysis is the mathematical formulation of the process of pixel value generation in the case of a given object (terrain) radiance distribution. The simplest assumption is that every pixel value is obtained by 
integrating the object radiance over a square corresponding to the area of the detector at the position of the pixel. The distribution of grey values of mixed pixels not only depends on the land cover pattern, but also on the spatial response of the sensor. Therefore, knowledge about the sensor point spread function can be used to enhance performance of spatial subpixel analysis [Kaiser et al., 2007]. The point spread function (PSF) describes the image of an infinitesimal object as obtained by an imaging system. The PSF, or its equivalent in the frequency domain, the optical transfer function (OTF), characterises the imaging system's spatial response, i.e. its spatial resolution. For our purpose we have to apply the model of the point spread function to objects on the earth's surface. The image of such an object is a summation of spatially distributed PSFs. Assuming shift invariance we can therefore describe the image as a convolution of the object with the point spread function of the imaging system (Castleman, 1995):

$$
I_{i}\left(x_{i}, y_{i}\right)=\int_{-\infty}^{\infty} \int_{-\infty}^{\infty} I_{0}\left(x_{0}, y_{0}\right) \cdot \operatorname{PSF}\left(x_{i}-x_{0}, y_{i}-y_{0}\right) d x_{0}, d y_{0}
$$

In this work we assume a Gaussian-shaped point spread function with two parameters, namely the standard deviations along the two image axes. These parameters are chosen such that the assumed PSF has characteristics as described in the MODIS Level 1A Earth Location Algorithm Theoretical Basis Document (ATBD). The MODIS PSF can be modeled by a triangle in the cross-track direction. This triangular shaped spatial response results from time integration of the signal recorded by the instrument behind the rotating mirror (MODIS SDS, 1997, Wolfe et al., 1998).

It has been shown that remotely sensed data are valuable for mapping the type, the areal extent and the patterns of snow and ice cover even in small catchment basins as input information for hydrological models. It has been demonstrated that the usefulness of MODIS image data of a very high temporal resolution (almost daily data acquisition potential) can be greatly enhanced by employing exact geolocation methods and subpixel analysis methods including the point spread function. Problems that remain to be treated are the influence of the angle of observation on the resulting NDSI values and snow area values, the performance of the method in forested areas, and the development of improved snow depletion models (e.g. with input data from digital elevation models).

For the purpose of determining the high resolution snow cover pattern for a given MODIS input, the snow cover model is cut at different heights. Every cut leads to a slice representing the corresponding snow cover pattern. For every height (slice) the correlation of fractional snow cover values and the according MODIS NDSI value is computed. The fractional snow cover values are obtained by aggregating the binary snow cover data with respect to the MODIS pixels' GIFOV and the MODIS PSF. Finally, that slice is selected which leads to the overall best fit to the MODIS NDSI image, i.e. which results in the highest correlation coefficient (R) between the MODIS NDSI and the aggregated fractional snow cover values. The snow cover pattern of the chosen slice is elected to represent the high resolution depletion pattern for the accordant date of MODIS image acquisition. 

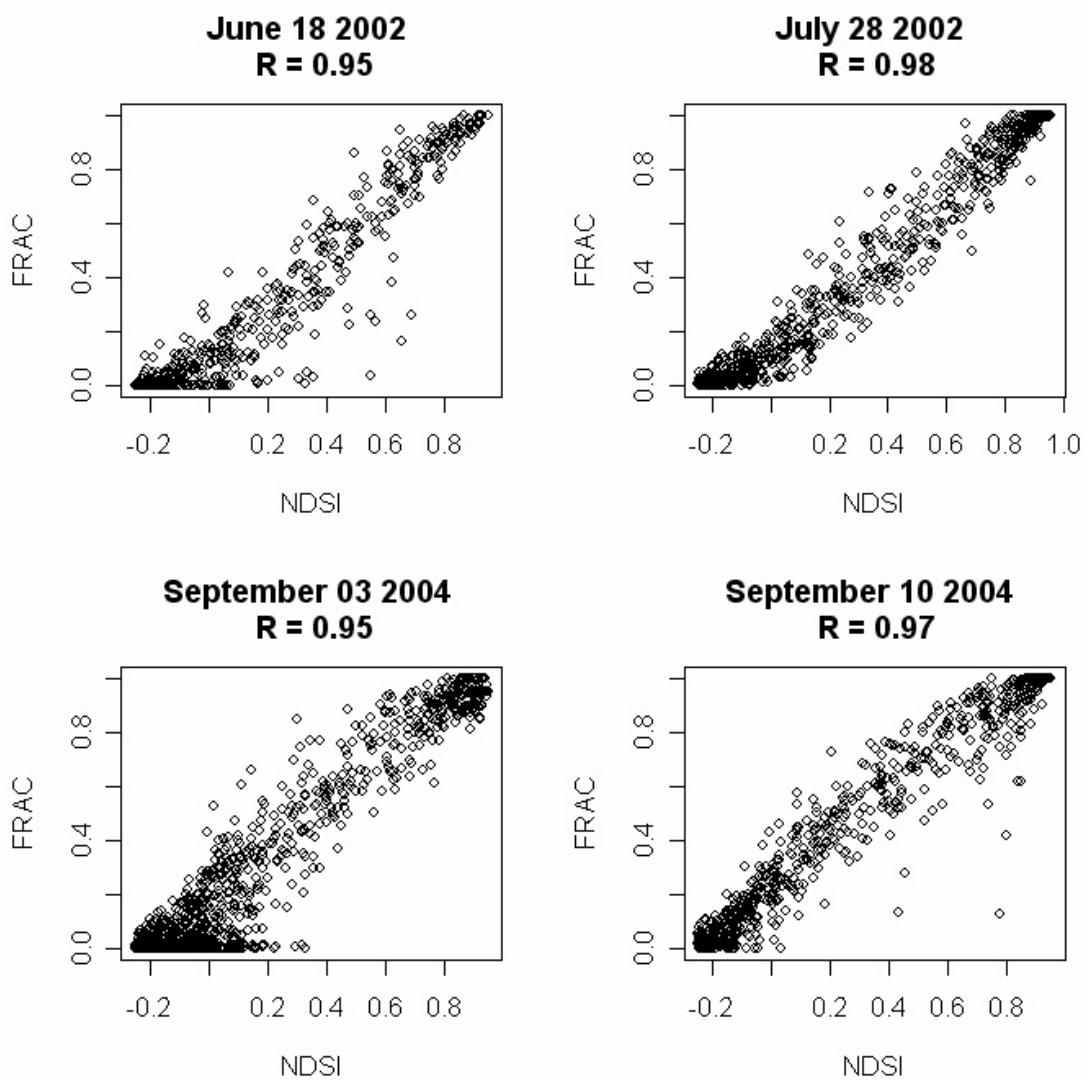

Figure 23: Correlation between NDSI-values of MODIS pixels and the fraction of snow area as determined from Landsat or ASTER images. from (Kaiser et al., 2007)

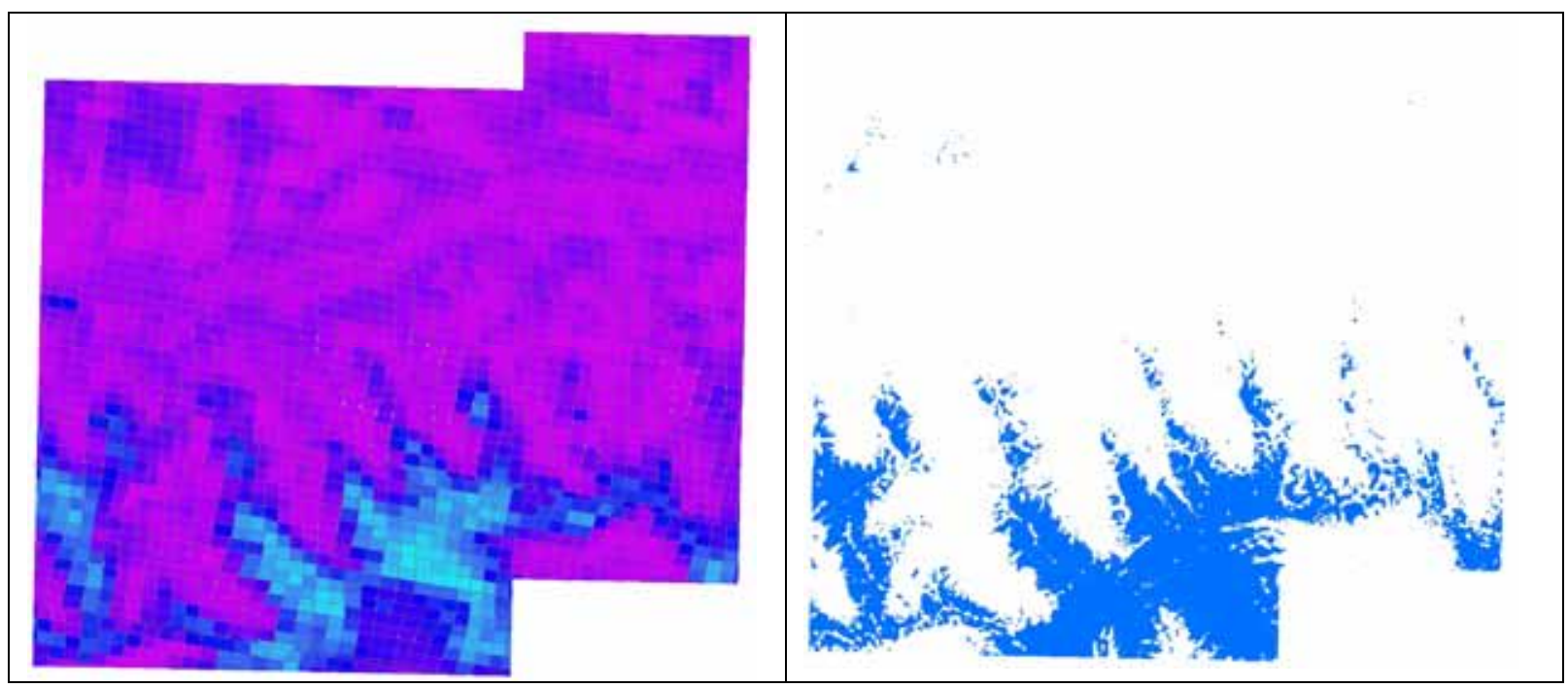

Figure 24: Mittersill: MODIS NDSI map of 21. 7. 2004, high resolution snow map derived from it. from (Kaiser et al., 2007)

The MODIS program provides various "data products" for operational use. Among these, there is also a Snow cover product (MOD10). The data are based on a snow mapping algorithm that employs the Normalized Difference Snow Index (NDSI). The geometric basis is a $500 \mathrm{~m}$ pixel grid in sinusoidal projection, which is the same as for the MOD09 product (Surface-Reflectance), as the MOD09 daily surface reflectance product is the primary input to the algorithm for producing MOD10. Figure 25: Comparison of correlations between NDSI and snow area for the precise NDSI mapping developed in this project (left) and NDSI 
mapping from the standard MODIS data product (right) MOD10 or the NDSI produced from MOD09 does not have the same quality as the dataset generated in this project: Fig. 36 shows the correlation between the NDSI value and the snow area for the precise NDSI mapping developed in this project (taking into account point spread function) (left) and NDSI mapping from the standard MODIS data product (right). The correlation is seen to be much better for the precise mapping.

September 10 2004, MOD02 $\mathbf{R}=\mathbf{0 . 9 7}$

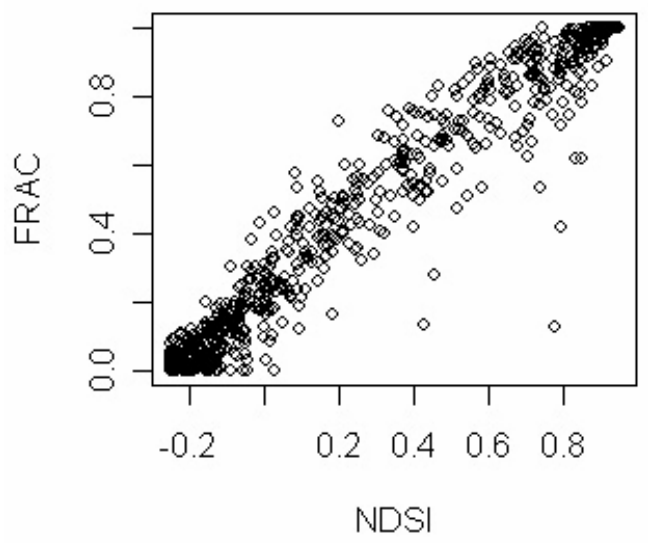

September 10 2004, MOD09 $\mathbf{R}=\mathbf{0 . 8 4}$

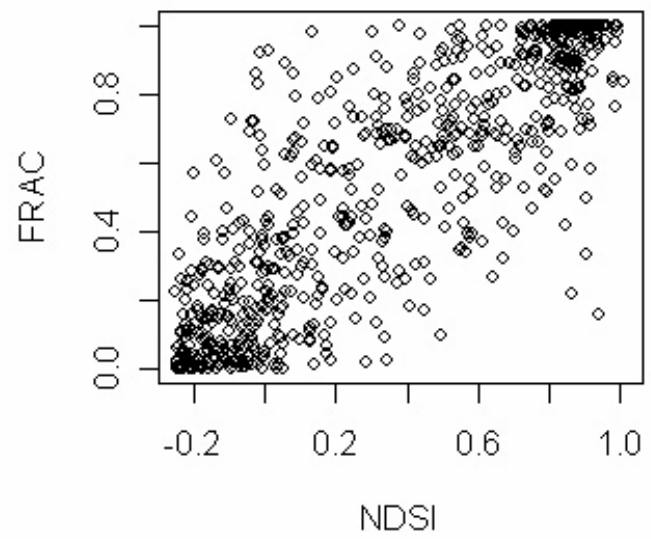

Figure 25: Comparison of correlations between NDSI and snow area for the precise NDSI mapping developed in this project (left) and NDSI mapping from the standard MODIS data product (right). from (Kaiser et al., 2007)

\section{Summary and conclusions}

The project SNOWTRANS provided an excellent opportunity to bring together scientists from different disciplines like meteorology, glaciology, hydrology and remote sensing. The research was balanced between field experiments, application and development of simulation models based on approved concepts, but the integration of new approaches indicated the potential to enhance the knowledge of snow and icemelt processes.

The extensive field campaigns during the project phase 2003 to 2006 in combination with the meteorological observatory Sonnblick brought a wide data base of snow and ice characteristics and formed the basement for process understanding and model validation. In particular the measurements included snow depth, snow density, snow temperature, spatial distribution of snow, ice sheet extent and ice ablation. But nonetheless it could obviously be seen, that meteorological processes in high altitudes reflect extreme behaviour where not all of the particular processes can be monitored reliably. The observation of precipitation, where most of it falls as snow in the annual cycle, tends to underestimate the true values. Therefore a correction factor of approx. 1.25 for the estimation of the areal precipitation was introduced. Discharge as the integrative response of the melting processes could only be observed in the summer and autumn period to prevent measurement errors due to snow and ice blocking. Snow drifts by wind and avalanches exhibit some spatial pattern but are partly random processes, which cannot be forecasted precisely in time and space.

Therefore the simulation of the cryosphere processes by means of computer models form a reliable alternative to field observations, where the latter are a prerequisite for model validation. Concerning the runoff formation the melt input is of primary importance. 
Thus the melt routines have high impact on the simulation results. The applied concepts of index based models and energy balance models exhibited reasonable results. Both require some parameter calibration of the indices and the albedo respectively. The computational requirements with respect to computational time show advantage for the index type methods. The different applied spatial discretisations (grid, HRU, elevation bands) gave comparable results as long as the elevation zones are resolved reliably for temperature interpolation. A zoning of 100-200 meter elevation seemed to be sufficient.

For the small Goldberkees basin the runoff transformation occurs rapidly and a linear storage concept is sufficient for the melt rates as no soil layers developed in that area and no significant vertical processes take place. For the mean scale basins the melt input was subdivided in a quick response and a runoff passing the soil and groundwater storage. This could be achieved both by the PREVAH model and the BOKU model.

The transferability of model parameters, in particular the melt parameters, was tested within the area of the Hohe Tauern mountains. Within these distances (approx. $80 \mathrm{~km}$ ) the melt parameters were quite stable. This means, that one representative basin (e.g. Goldbergkees) can serve for calibration, where these parameters can be transferred to other basins in the surroundings. This excludes the retention parameters of the hydrological model, which reflect specific areas and flow distances of the basins of interest.

The contribution of the remote sensing group addressed the applicability of satellite images for model validation. As some of these products are available in a high temporal resolution, the can be used even for operational purposes (e.g. system updating of snow cover). It could also be shown, that from the different spectra of the sensors physical conditions of the snow cover (e.g. firn, fresh snow, water content) can be classified.

A further important contribution was the introduction of the subpixel analysis. This technique allows the recognition of spatial patterns of snow depletion from coarse image resolution by adapting some additional spatial information (e.g. high resolution DEM).

\section{Project Outcome}

Paper contributions are listed in the reference list and are highlighted in bold letters. In addition oral and poster presentations at workshops and conferences are listed here.

\section{Oral Presentations:}

\section{4:}

Koboltschnig, G., Holzmann, H., Schöner W. (2004): Vorstellung des Projektes:

Transformation of observed and computed ice- and snowmelt data to ungauged basins.

17. Sitzung des Sonnblickbeirates, 21. Oktober 2004, ZAMG Hohewarte, Wien.

Schöner, W., Auer, I., Böhm, R., Hynek, B., Holzmann, H., Koboltschnig, G. (2004):

Klimatische Bedingungen der extremen Gletscherschmelze in den Alpen im Jahr 2003.

8. Österreichischer Klimatag "Klima, Klimaänderung und Auswirkungen" der OEGM -

Österreichische Gesellschaft für Meteorologie, 19.+20. April 2004, BOKU, Wien.

Koboltschnig G., Holzmann H., Schöner W. (2004): Measuring and modeling of snow- and icemelt of the "Goldbergkees" glacier in Hohe Tauern region. AGM (Alpine Glaciology Meeting), 26.-27.2.2004, Innsbruck. 
2005:

Koboltschnig G., Holzmann H., Schöner W. (2005): Monitoring snow- and icemelt of two small glacierized catchments in the Austrian Alps. In: European Geosciences Union: EGU General Assembly 2005, 24.-29. April 2005, Vienna; Geophysical Research Abstracts, Vol. 7; ISSN 1029-7006.

Koboltschnig G., Holzmann H., Schöner W. (2005): Application of a water balance model for a small glacierized catchment in the Austrian alps. AGM (Alpine Glaciology Meeting), 24.-25.2.2005, Milano, Italien.

\section{6:}

Holzmann H., Koboltschnig G. 2006. Comparison of index based snowmelt models for different temporal and spatial scales. Alpine*Snow*Workshop. 5-6 October 2006, Munich.

Koboltschnig G., Holzmann H., Schöner W. 2006. SNOWTRANS: Transformation of observed and computed ice- and snowmelt data to ungauged basins. AGM (Alpine Glaciology Meeting), 23.-24.02.2006, Munich.

Koboltschnig G., Holzmann H., Schöner W., Zappa M. 2006. Capability of a water balance model with high temporal resolution for the modelling of ice- and snowmelt processes at high elevated sites. 63rd Eastern Snow Conference , 7-9 June 2006, Newark, Delaware, USA.

Koboltschnig G., Neuschitzer F., Schöner W., Holzmann H. 2006. Zuflusssituationen hochalpiner Speicher mit vergletscherten Einzugsgebieten. Stauhaltungen und Speicher - Von der Tradition zur Moderne, 27-30 September 2006, Graz.

Koboltschnig G. (2006): Beschreibung der Eis- und Schneeschmelzprozesse in hochalpinen Einzugsgebieten als Beitrag zur Abflussbildung, A multi-validation approach. Vortragsreihe: „Junge Hydrologie Österreichs“ der Österreichischen Gesellschaft für Hydrologie , 16.11.2006, Wien.

Koboltschnig G., Holzmann H., Schöner W., Zappa M. (2006): Contribution of glacier melt to stream runoff: if the climatically extreme summer of 2003 had happened in 1979 .... International Symposium on Cryospheric Indicators of Global Climate Change, 21-25 August 2006, Cambridge, UK.

\section{7:}

Holzmann H., Koboltschnig G., Rauch L. Schöner W. 2007: COMPARISON OF HYDROLOGICAL MODULES FOR GLACIER MELT PROCESSES, Workshop Glaciers in Watershed and Global Hydrology, 27-31 August 2007, Obergurgl, Austria Koboltschnig G. (2007): Klimaänderung und Auswirkungen auf die Wasserwirtschaft. Abteilungstag der Abt. 18 Wasserwirtschaft, Kärntner Landesregierung, 19.08.2007, Kongresszentrum Pörtschach am Wörthersee.

Koboltschnig G. (2007): The impact of the 2003 summer heat wave on glacierized Alpine catchments: an outlier or a possible future scenario? International Conference 'Managing Alpine Future', 17.10.2007, Innsbruck.

Koboltschnig G., Holzmann H., Kroisleitner Ch., Schöner W., Zappa M. (2007): Missing snow: calibration and validation of a water balance model in a glacierized high alpine basin. AGM (Alpine Glaciology Meeting), 1. - 2. March 2007, ETH-VAW, Zürich.

Koboltschnig G:, Holzmann H., Kroisleitner Ch., Schöner W., Zappa M. 2007: SIMULATED GLACIER MELT CONTRIBUTION ON DIFFERENT SPATIAL SCALES: TRANSFERABILITY AND MULTIVALIDATION OF MODEL PARAMETERS, Workshop Glaciers in Watershed and Global Hydrology, 27-31 August 2007, Obergurgl, Austria 
Michlmayr G., Holzmann H., Koboltschnig G., Lehning M., Mott R., Schöner W., Zappa M. 2007: APPLICATION OF A PHYSICALLY BASED MOUNTAIN SURFACE PROCESSES MODEL TO SIMULATE SNOW AND ICE MELT ON GOLDBERGKEES GLACIER (AUSTRIA), Workshop Glaciers in Watershed and Global Hydrology, 27-31 August 2007, Obergurgl, Austria

\section{Poster Presentations:}

\section{6:}

Koboltschnig G., Holzmann H., Schöner W. 2006. Waterbalance of a small and highly glacierized alpine Catchment (poster). In: European Geosciences Union, General Assmbly of the European Geosciences Union, 02-07 April 2006, Vienna; SRef-ID: 1607-7962/gra/EGU06-A-04095, Geophysical Research Abstracts, Vol. 8. $^{1}$

Koboltschnig G., Holzmann H., Schöner W., Zappa M. 2006. Contribution of glacier melt to stream runoff: if the climatically extreme summer of 2003 had happened in 1979 ... (poster). International Symposium on Cryospheric Indicators of Global Climate Change, 21-25 August 2006, Cambridge, UK. ${ }^{2}$

Koboltschnig G., Holzmann H., Schöner W., Zappa M. 2006. Multi-validation approach of a water balance model with high temporal resolution for the modelling of ice- and snowmelt processes at high elevated sites (poster). Alpine*Snow*Workshop. 5-6 October 2006, Munich.

Michlmayr G., Holzmann H., Koboltschnig G., Lehning M., Mott R., Schöner W., Zappa M. 2006: Physically based snow and ice melt modelling. In: European Geosciences Union, General Assmbly of the European Geosciences Union, 02-07 April 2006

\section{Papers and reports:}

KOBOLTSCHNIG G., SCHÖNER W., HOLZMANN H. (2007): Extensive hydrological monitoring of a small, highly glacierized watershed in the Hohe Tauern region, Austrian Alps. IAHS Publ., 318, 95-104; ISSN 0144-7815.

Koboltschnig G.R., Schöner W., Zappa M., Holzmann H. (2007): Contribution of glacier melt to stream runoff: if the climatically extreme summer of 2003 had happened in 1979 .... ANN GLACIOL, 46, 303-308; ISSN 0260-3055.

Koboltschnig G., Holzmann H., Schöner W., Zappa M.(2006): Potential of a Water Balance Model with High Temporal Resolution for the Distributed Modelling of Ice- and Snowmelt Processes at High Elevated Sites . In: Robert Hellström and Susan Frankenstein (Eds.), Proceedings of the 2006 Annual Meeting, 63rd Eastern Snow Conference, 7-9 June 2006, Newark, Delaware, USA, 19-36.

Koboltschnig G., Neuschitzer F., Schöner W., Holzmann H. (2006): Zuflusssituationen hochalpiner Speicher mit vergletscherten Einzugsgebieten. In: Technische Universität Graz, Institut für Wasserbau und Wasserwirtschaft, Stauhaltungen und Speicher - Von der Tradition zur Moderne, 27-30 September 2006, Graz, Schriftenreihe zur Wasserwirtschaft, Technische Universität Graz, 46/1.

Koboltschnig G., Holzmann H., Schöner W.(2005): Application of a water balance model for a small glacierized catchment in the Austrian alps. In: Smiraglia C., Carinelli T., 9th Alpine Glaciological Meeting, Abstracts of oral presentations, Earth Science Department "Ardito Desio" University of Milan, AGM (Alpine Glaciology Meeting), 24.-25.2.2005, Milano, Italien.

\footnotetext{
${ }^{1}$ siehe Abstract und kleinformatiges Poster im Anhang

${ }^{2}$ siehe kleinformatiges Poster im Anhang
} 
Koboltschnig, G., Schöner, W., Holzmann, H.(2005): Monitoring und Modellierung der Schnee- und Eisschmelze eines vergletscherten Einzugsgebietes in den Hohen Tauern. In: Inst. f. Wasserbau und Wasserwirtschaft, TU-Graz: 7. Treffen junger WissenschaftlerInnen deutschsprachiger Wasserbauinstitute (JUWI), 3.-6. August 2005, Graz; Schriftenreihe zur Wasserwirtschaft, 43, 43-48; Verlag der Technischen Universität Graz; ISBN 3-902465-22-0.

Koboltschnig G., Holzmann H., Schöner W. (2004): Measuring and modelling snow melt and glacier runoff at Goldbergkees in Hohe Tauern (Austrian Alps). In: Andreas Herrmann: International Conference on Hydrology of Montain Environments, 27. Sept- - 1. Okt 2004, Berchtesgaden, Deutschland; Landschaftsökologie und Umweltforschung, Extended Abstracts, 47, 191-195; Selbstverlag Institut für Geoökologie der Technischen Universität Braunschweig, Braunschweig; ISSN 0170-7299.

Schöner W., Auer I., Böhm R., Hynek B., Holzmann H., Koboltschnig G. (2004): Extreme glacier melt in Hohe Tauern region (Austrian Alps). In: Andreas Herrmann: International Conference on Hydrology of Mountain Environments, 27. Sept - 1. Okt 2004, Berchtesgaden, Deutschland; Landschaftsökologie und Umweltforschung, Extended Abstracts, 47, 319-322; Selbstverlag Institut für Geoökologie der Technischen Universität Braunschweig, Braunschweig; ISSN 0170-7299.

Mott, R., F. Faure, G. Koboltschnig, M. Lehning, H. Löwe, G. Michlmayr, A. Prokop, W. Schöner (2007 b ): Simulation of seasonal snow cover development and seasonal snowcover distribution for glaciated sites (Sonnblick, Austrian Alps) with the ALPINE3D model.

Kaiser, G., W. Schneider, F. Suppan, M. Vollmann (2007): Snowmelt processes and remote sensing. Final report SNOWTRANS - remote sensing group.

\section{Diploma Thesis:}

Binder D. (2007). GPR Messung und Modellierung der Eisdicke auf den Gletschern Kleinfleißkees und Goldbergkees. Diplomarbeit an der Universität und TU Wien.

Michlmayr G. (2007). Verteilte Schneeschmelzmodellierung mittels physikalisch basiertem Energiebilanzmodell ALPINE3D. Diplomarbeit an der Universität für Bodenkultur, CoBetreuung vom SLF in Davos.

Mott R. (2007). Physikalisch basierte Schneedeckensimulation mit ALPINE3D auf Basis von Monitoringdaten aus dem Gebiet des Hohen Sonnblick. Diplomarbeit an der Universität Wien, Co-Betreuung von der ZAMG, dem IWHW-BOKU und dem SLF in Davos.

Rauch L. (2007). Schneeschmelzmodellierung mit indexbasierten Modellen. Diplomarbeit an der Universität für Bodenkultur.

Unterfrauner F. (in prep.). Hydrologische Fließ- und Speicherzeit Untersuchungen der Schneedecke und des interglazialen Abflusssystems mit Hilfe von Markierungstracern. Diplomarbeit an der Universität Wien, Co-Betreuung von der ZAMG und dem IWHWBOKU.

Vollmann M. (2007). Kartierung von Ausaperungsmustern aus Satellitenbildern, Diplomarbeit an der Universität für Bodenkultur, Institut für Vermessung, Fernerkundung und Landinformation (IVFL), Co-Betreuung von der ZAMG und dem IWHW-BOKU.

\section{Doctoral Thesis:}

Koboltschnig G. 2007: Multivalidation approach of hydrological snow and ice melt models in high alpine, glaciated catchments. Doctoral thesis at the BOKU university, Vienna. 


\section{Acknowledgements}

The authors give their special acknowledgements to the Austrian Academy of Sciences for the funding of the research project SNOWTRANS - Transformation of observed and computed ice- and snowmelt data to ungauged basins.

\section{References}

References in bold letters represent results and outcome of the project SNOWTRANS.

Bartelt, P. and M. Lehning: 2002. A physical Snowpack model for the Swiss avalanche warning: Part I: numerical model. Cold Regions Science and Technology 35 : 123-145. DOI: 10.1016/S0165232X(02)00074-5

Castleman, K. R. (1995): Digital Image Processing. Prentice Hall.

Gurtz J., Zappa M., Jasper K., Lang H., Verbunt M., Badoux A., Vitvar T. 2003. A Comparative Study in Modelling Runoff and its Components in Two Mountainous Catchments. Hydrological Processes 17: 297-311. DOI: 10.1002/hyp.1125

Habersack H.M., Krapesch G., Holzmann H., Koboltschnig G. (2006): Hitze- und Dürrefolgen für die Wasserwirtschaft Österreichs. Verbund, 72.Hynek B., Schöner W. 2004. Massenhaushalt 2002/2003 der Gletscher in der Goldberggruppe. 101.-102. Jahresbericht des Sonnblick-Vereines: 1-15. Eigenverlag der Zentralanstalt für Meteorologie und Geodynamik, Wien.

Hoinkes H. 1970. Methoden und Möglichkeiten von Massenhaushaltsstudien auf Gletschern. Ergebnisse der Meßreihe Hintereisferner (Ötztaler Alpen) 1953 - 1968. Zeitschrift für Gletscherkunde und Glazialgeologie, 6, 37 - 90.

Holzmann, H., Nachtnebel, H.P. (2002): Abflussprognose für mittelgroße Einzugsgebiete Methodik und Anwendungen.. Österr. Wasser- und Abfallwirtschaft, 54, 9-10, 142153.Hynek, B. (2006): Energiebilanz des Goldbergkees während des Sommers 2003. Diplomarbeit am Institut für Meteorologie der Universität Wien, Austria.

Holzmann, H. (2006): Benutzerbeschreibung eines höhenverteilten Schneeschmelzmodells. IWHW-BOKU, Eingenverlag.

Holzmann H., Koboltschnig G., Rauch L. Schöner W. 2007: COMPARISON OF HYDROLOGICAL MODULES FOR GLACIER MELT PROCESSES, Workshop Glaciers in Watershed and Global Hydrology, 27-31 August 2007, Obergurgl, Austria Hynek B., Schöner W. 2004. Massenhaushalt 2002/2003 der Gletscher in der Goldberggruppe. 101.-102. Jahresbericht des Sonnblick-Vereines: 1-15. Eigenverlag der Zentralanstalt für Meteorologie und Geodynamik, Wien.

Jansson, P., Hock, R., Schneider, Th. (2003) The concept of glacier storage: a review. J. Hydrol. 282 (2003), 116-129.

Kaiser, G., Schneider, W., Suppan, F., Vollmann, M. (2007a): Snow cover analysis by remote sensing. Final report for the project SNOWTRANS, BOKU Vienna.

Kaiser, G. and W. Schneider (2007b): Estimation of sensor point spread function by spatial subpixel analysis, Remote Sensing of Environment, In press.

Kaser G., Fountain A., Jansson P. (2003): A manual for monitoring the mass balance of mountain glaciers. IHP-VI, Technical Documents in Hydrology No. 59, UNESCO, Paris, 2003.

Kling, H., Fürst, J., Nachtnebel, HP. (2006): Seasonal, spatially distributed modelling of accumulation and melting of snow for computing runoff in a long-term, large-basin water balance model. Hydrological Processes, 20, 2141-2156.

Koboltschnig G. (2007a): Multivalidation approach of hydrological snow and ice melt models in high alpine, glaciated catchments. Doctoral thesis at the BOKU university, Vienna. 
Koboltschnig G., Schöner W., Holzmann H. (2007b): Extensive hydrological monitoring of a small, highly glacierized watershed in the Hohe Tauern region, Austrian Alps. IAHS Publ., 318, 95-104; ISSN 0144-7815.

Lehning M, Voelksch I, Gustafsson D, Nguyen T, Staehli M, and Zappa M. (2006). A detailed model of mountain surface processes and its application to snow hydrology. Hydrological Processes. 20: 2111 - 2128.

Lehning M, Bartelt P, Bethke S, Fierz C, Gustafsson D, Landl B, Lütschg M, Martius O, Meirold I, Raderschall N, Rhyner J, Stähli M. (2004). Review of SNOWPACK and ALPINE3D applications. In Snow Engeneering, Bartelt P., Sack R, Sato A, Adams E, Christen M(eds). Balkema: The Netherlands; 299 - 307.

Lehning M., Doorschot J., Bartelt P. (2000). A snowdrift index based on SNOWPACK model calculations. In Annals of Glaciology, 31: 382-386.

Michlmayr G. 2007. Simulation von Schnee- und Eisschmelzprozessen in hochalpinem Raum. Diplomarbeit an der Universität für Bodenkultur Wien.

MODIS Science Data Support Team (1997): MODIS Level 1A Earth Location: Algorithm Theoretical Basis Document. Version 3.0

Mott, R. (2007a): Modellierung der zeitlichen Entwicklung und r "aumlichen Verteilung einer saisonalen Schneedecke vergletscherter Gebiete (Sonnblick) mit dem physikalisch basierten Modell ALPINE3D. Diploma thesis at BOKU University Vienna.

Mott, R., F. Faure, G. Koboltschnig, M. Lehning, H. Löwe, G. Michlmayr, A. Prokop, W. Schöner (2007 b ): Simulation of seasonal snow cover development and seasonal snowcover distribution for glaciated sites (Sonnblick, Austrian Alps) with the ALPINE3D model.

Nash J.E., Sutcliffe J.V. 1970. River flow forecasting through conceptual models (1), a discussion of principles. Journal of Hydrology 10 (3): 282-290.

Oke, T. R. 2000. Boundary Layer Climates, 2nd edition. Routledge. London.

Østrem, G., and Brugman, M. (1991) Glacier mass-balance measurements. A manual for field and office work: Environment Canada, National Hydrology Research Institute Science Report No. 4, and Norwegian Water Resources and Energy Administration, 224 p.

Rauch L. (2007). Schneeschmelzmodellierung mit indexbasierten Modellen. Diplomarbeit an der Universität für Bodenkultur.

Schöner, W., Auer, I., Böhm, R., Hynek, B., Holzmann, H., Koboltschnig, G. (2004): Extreme glacier melt in Hohe Tauern region (Austrian Alps). In: Andreas Herrmann: International Conference on Hydrology of Mountain Environments, 27. Sept- - 1. Okt 2004, Berchtesgaden, Deutschland; Landschaftsökologie und Umweltforschung, Extended Abstracts, 47, 191-195; Selbstverlag Institut für Geoökologie der Technischen Universität Braunschweig, Braunschweig; ISSN 0170-7299.

Schöner W., Hynek B. 2006. Massenhaushalt 2004/2005 der Gletscher in der Goldberggruppe: Goldbergkees, Kleinfleißkees, Wurtenkees. Jährlicher Bericht der Klimaabteilung der ZAMG Wien.

Singh, P. \& Bengtsson, L. (2005) Impact of warmer climate on melt and evaporation for the rainfed, snowfed and glacierfed basins in the Himalayan region. J. Hydrol. 300 (2005) 140-154.

Vollmann M. (2007). Kartierung von Ausaperungsmustern aus Satellitenbildern, Diplomarbeit an der Universität für Bodenkultur, Institut für Vermessung, Fernerkundung und Landinformation (IVFL), Co-Betreuung von der ZAMG und dem IWHW-BOKU.

Wolfe, R.E. , D.P. Roy and E.F. Vermote (1998): The MODIS land data storage, gridding and compositing methodology: Level 2 Grid, IEEE Transactions on Geoscience and Remote Sensing, Vol. 36, pp. 1324-1338, 1998. 
Zappa M., Pos F., Strasser U., Gurtz J. 2003. Seasonal water balance of an alpine catchment as evaluated by different methods for spatially distributed snow melt modelling. Nordic Hydrology 34(3): 179-202 